\title{
Wealth and inheritance in Britain from 1896 to the present
}

\author{
Anthony B. Atkinson ${ }^{1,2,3}$
}

Published online: 21 June 2018

(C) The Author(s) 2018

\begin{abstract}
Personal wealth has grown since the 1970s twice as fast in real terms as national income. Has this rise in the wealth-income ratio led to a corresponding increase in the wealth being passed on from one generation to the next? Are we returning to the levels of inheritance found in the 19th century? The aim of this paper is to construct UK evidence on the extent of the transmission of wealth in the form of estates and gifts inter vivos. It takes a long-run view of inheritance, starting from 1896, when the modern Estate Duty was introduced, and exploits the extensive estate data published over the years. Construction of a long-run time series for more than a century is challenging, and there are important limitations. The resulting time-series demonstrates the major importance of inheritance in the UK before the First World War, when the total transmitted wealth represented some 20 per cent of net national income. In the inter-war period, the total was around 15 per cent, falling to some 10 per cent after the Second World War, and then falling further to below 5 per cent in the late 1970s. Since then, there has indeed been an upturn: a rise from 4.8 per cent in 1977 to 8.2 per cent in 2006. This increase was more or less in line with the increase
\end{abstract}

Note by the editors: Tony Atkinson presented the first version of this article at the Workshop "Inequality, Crisis and Taxation" (Centre of Advanced Studies of Paris, 7 March 2012), and shortly afterwards published it as LSE-CASE Working Paper 179/2013. Some of the series were subsequently updated in Alvaredo et al. (2017, 2018). We have minimally edited the latter for inclusion in this issue.

This research was stimulated by the work of Thomas Piketty on France (2011). The author is grateful to him and to Facundo Alvaredo and John Hills for helpful suggestions. Financial support from ESRC/DFID (through grant ES/I033114/1) and the Institute for New Economic Thinking (through Grant INO14-00023) is gratefully acknowledged.

Anthony B. Atkinson

richard.t.atkinson@icloud.com

1 Nuffield College, Oxford, UK

2 Institute for New Economic Thinking at the Oxford Martin School, Oxford, UK

3 London School of Economics, London, UK 
in personal wealth, and has to be interpreted in the light of the changing net worth of the corporate and public sectors of the economy.

Keywords Wealth $\cdot$ Inheritance $\cdot$ Estate data

\section{Introduction}

There has been a large rise in the ratio of personal wealth to national income. In the United Kingdom, at the end of the 1970s the ratio of personal net worth, excluding pension rights, to net national income was under 3; today it is over 5. Personal wealth grew over this period faster than national income at a rate of some 2 per cent per annum-about twice as fast in real terms. The rise in the wealth-income ratio is one reason that the rise in top income shares has not led to the same rise in top wealth shares: the denominator has been rising as well as the numerator. Between 1979 and 2005, the share of the top 1 per cent in total income more than doubled, but the share of the top 1 per cent in total personal wealth rose by less than 1 percentage point (Atkinson 2007; Alvaredo et al. 2018).

Has this rise in the wealth-income ratio led to a corresponding increase in the wealth being passed on from one generation to the next? To the extent that the same assets (such as houses and businesses) are owned, but there has been a rise in their relative price, we may expect inheritance to rise in line. On the other hand, the rise in the significance of personal wealth may result from increased life-cycle savings. The rise in the wealth-income ratio may just be a reflection of the fact that people are expecting to spend longer in retirement. The simplest life-cycle model, with the rate of growth equal to the rate of interest, suggests that the wealth- income ratio rises by 0.5 for each extra year of expected retirement (Modigliani (1986), page 301). In that case, no more may be passed on in inheritance. But if we allow for the existence of state and private pension schemes (the figures quoted above exclude pension wealth), then 0.5 has to be scaled down by (approximately) a factor of (1-replacement rate). Moreover, as shown by Piketty (2009), the rise in the ratio is less marked when the rate of interest exceeds the rate of growth. The sensitivity of the calculations regarding the wealth-income ratio does indeed suggest that we cannot rely solely on simulations and have to consider the empirical evidence.

The focus of this paper is on the empirical importance of inheritance in the UK. Has the rise in the personal wealth-income ratio been accompanied by a rise in bequests? The immediate motivation comes from the pioneering study for France by Piketty (2011), which shows that inheritance has returned after a period of decline. In France, the annual wealth transmitted fell from some 20 to 25 per cent of national income between 1820 and 1910 to around 2.5 per cent in 1950 , but has since risen to around 15 per cent in 2010 . In his paper, he comments that "unfortunately there does not seem to exist any other country with estate tax data that is as long term and as comprehensive as the French data" Piketty (2011, page 1077). This paper takes up this challenge. As far as the UK is concerned, he is correct: the data are less adequate. The data employed here start only in 1896, and they are less complete with regard to gifts. But they can be used. Indeed, Karagiannaki has investigated the evolution of inheritance in the UK over the period 1984 to 2005, finding that in this period "the annual flow of inheritance increased markedly" (2011, page iii).

The aim of this paper is to construct UK evidence on the extent of the transmission of wealth in the form of estates and, insofar as it is possible, gifts inter vivos. It follows Piketty 
(2011) in taking a long-run view of inheritance, starting from 1896, when the modern Estate Duty was introduced by Harcourt in the 1894 Finance Act. Piketty $(2009,2011)$ uses two approaches to the measurement of inheritance. The first is a direct measure of the flows of bequests and gifts using the rich fiscal data in France; the second is an indirect measure built up from mortality and wealth ownership data (this method in effect inverts the standard estate multiplier method of estimating the wealth of the living - see Atkinson and Harrison (1978)). This paper is based on the first method, exploiting the extensive estate data published over the years in the UK. (The second approach is used in making certain corrections to the estate-based estimates.) The sources and methods are described in Section 3. Construction of a long-run time series for more than a century is indeed challenging, and it is important to understand the limitations of the resulting estimates. The findings are set out in Section 4. One of the aims of the research is to compare the findings with those of Piketty for France, and this is the subject of Section 5. The comparison is of interest both on account of the similarities of the two countries and on account of the differences, notably in the case of England and Wales concerning the freedom of bequest, which differentiates these parts of Great Britain from France (and Scotland). As Josiah Wedgwood remarked, "few Englishmen realise how great is the difference between the European laws of succession and their own" $(1929,1939$, page 91).

Before embarking on the estimation of the extent of inherited wealth, I begin in Section 2 by seeking to set the UK rise in the wealth-income ratio within the context of changes in asset prices and changes in the net worth of other sectors of the UK economy.

\section{Background: The recent rise in personal wealth}

The evolution of the ratio of personal wealth to net national income in the UK since 1920 is presented in Fig. 1. This shows the increase that has taken place in the past 30 years. If this rise in the wealth-income ratio were the result of purely demographic developments, then we should expect it to have happened gradually over the post-war period. Life expectancy at age 65 has increased steadily. The average effective age of retirement for men in the UK fell more between 1950 and 1980 than between 1980 and 1995, whereas the wealth-income ratio fell from around 4 in 1950 to under 3 in 1980.

The U-shaped pattern since 1950 must reflect other factors. One obvious hypothesis is suggested by the timing of the turning point, which coincided with the election in 1979 of a Conservative Government led by Mrs Thatcher. Policies changed in directions that impacted directly on household wealth, most evidently the commencement of privatisation, which led to the sale of state owned assets, including shares in nationalised industries and state-owned housing (through the "Right to Buy" sale of council houses). I begin with housing, since one natural reaction to Fig. 1 is to say that "it is all to do with rising house prices."

Owner-occupation in the UK increased rapidly over the post-war period: in England and Wales, from 31 per cent in 1951 to 58 per cent in 1981 (Holmans 2000, Table 14.12). Insofar as this was accompanied by a fall in private landlords, there was no change in the sector of ownership. Indeed, total personal ownership of houses fell from 82 per cent in 1951 to 69 per cent in 1981. There was an increase in state-owned housing. This was reversed following 1979 by the sale of council houses, which meant that the total personal ownership of houses rose to 77 per cent in 1991. This explains part of the U shape. The upswing was re-inforced by the relative rise in housing prices that took place in the later part of the period. In 1970 


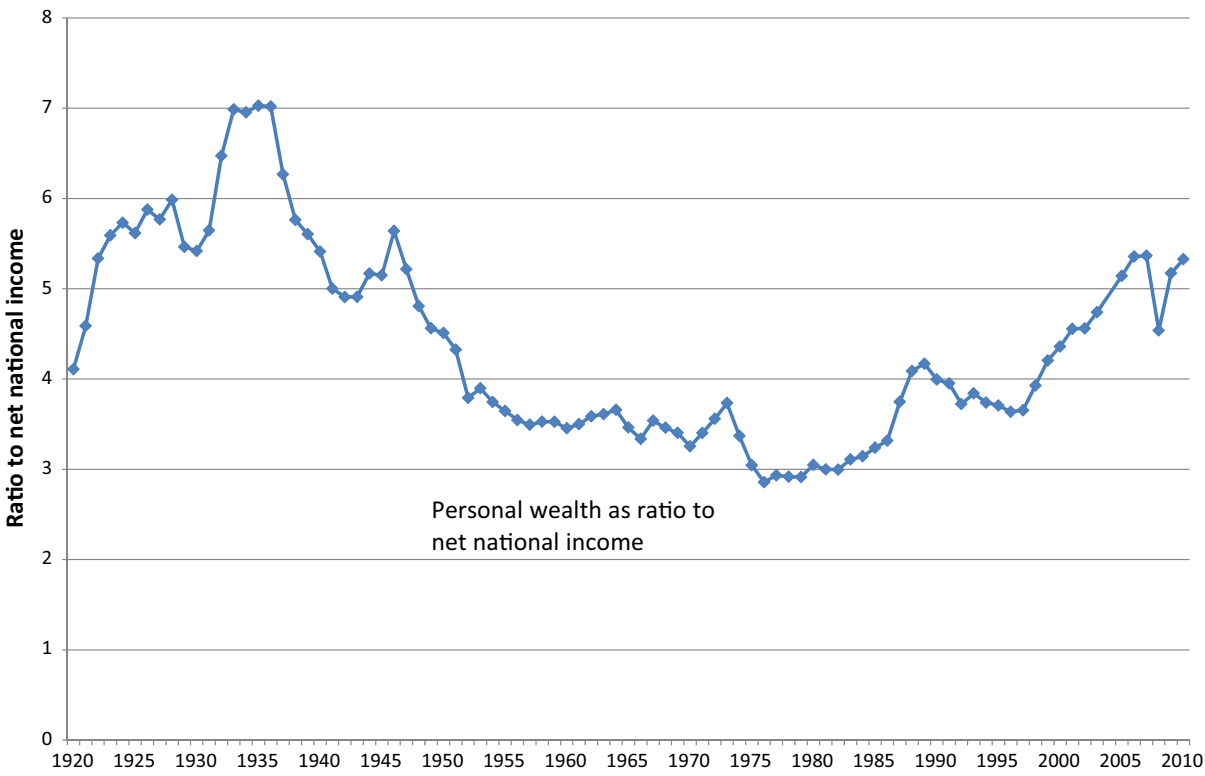

Fig. 1 Personal wealth in the United Kingdom from 1920 to 2010 as ratio to net national income

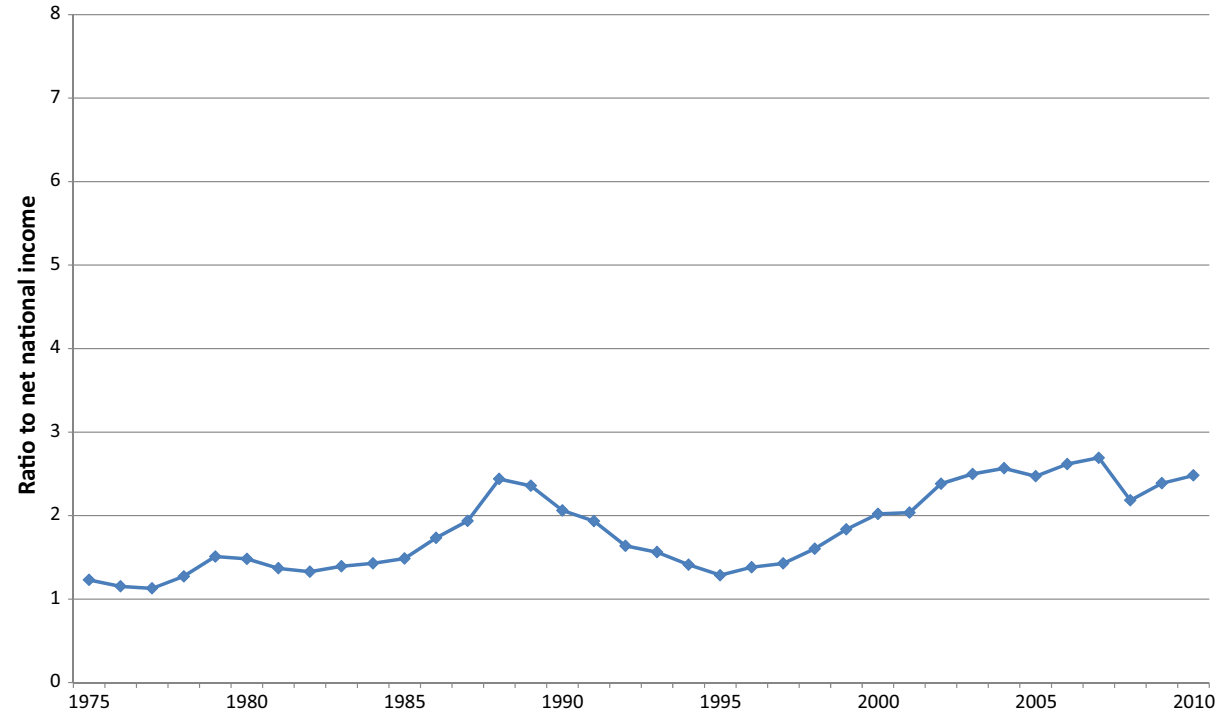

Fig. 2 Housing net worth in the United Kingdom from 1975 to 2010 as ratio to net national income 
UK house prices were no higher relative to consumer prices than in 1948, but between 1970 and 2009 house prices doubled in real terms.

There were therefore two forces at work over the post-war period: a fall and then a rise in the proportion of the housing stock owned by persons, and a rise in relative house prices in the second part of the period. Both of these factors combined to raise the personal wealthnational income ratio in the later part of the period. As may be seen from Fig. 2, housing net wealth (taken from the national balance sheets, subtracting the mortgage and other housingrelated debt) made a sizeable contribution. It accounted for a third of the overall rise in the personal wealth-income ratio. As has been emphasised by Karagiannaki (2011a), the change in personal wealth between 1995 and 2005 was almost entirely due to housing. But, over the longer run, housing is not the whole story as far as the personal sector is concerned. Comparing the two graphs, drawn with the same vertical scale, it may be seen that housing accounts for about half of the increase since the 1970s.

In seeking to understand the other factors in operation, it is instructive to look at total national wealth, again expressed as a ratio to net national income-see Fig. 3. The ratio rose in the first part of the period but then stabilised. From 1957 to 1979 the ratio went from under 4 to over 6. But in 2010 it was at much the same level as in 1979. If housing is deducted, then the ratio fell steadily from 1979. The recent rise in the personal wealthincome ratio must therefore have come at the expense of falling net worth of other sectors. In the same way, the rise in national wealth before 1979 must have been associated with a rise in the net worth of other sectors, since the personal wealth-income ratio was falling.

Figure 4 shows the net worth position of the corporate and public sectors. The corporate sector includes private non-financial corporations and financial corporations. In his study The wealth of the nation, Revell (1967) drew attention to the fact that the value of company

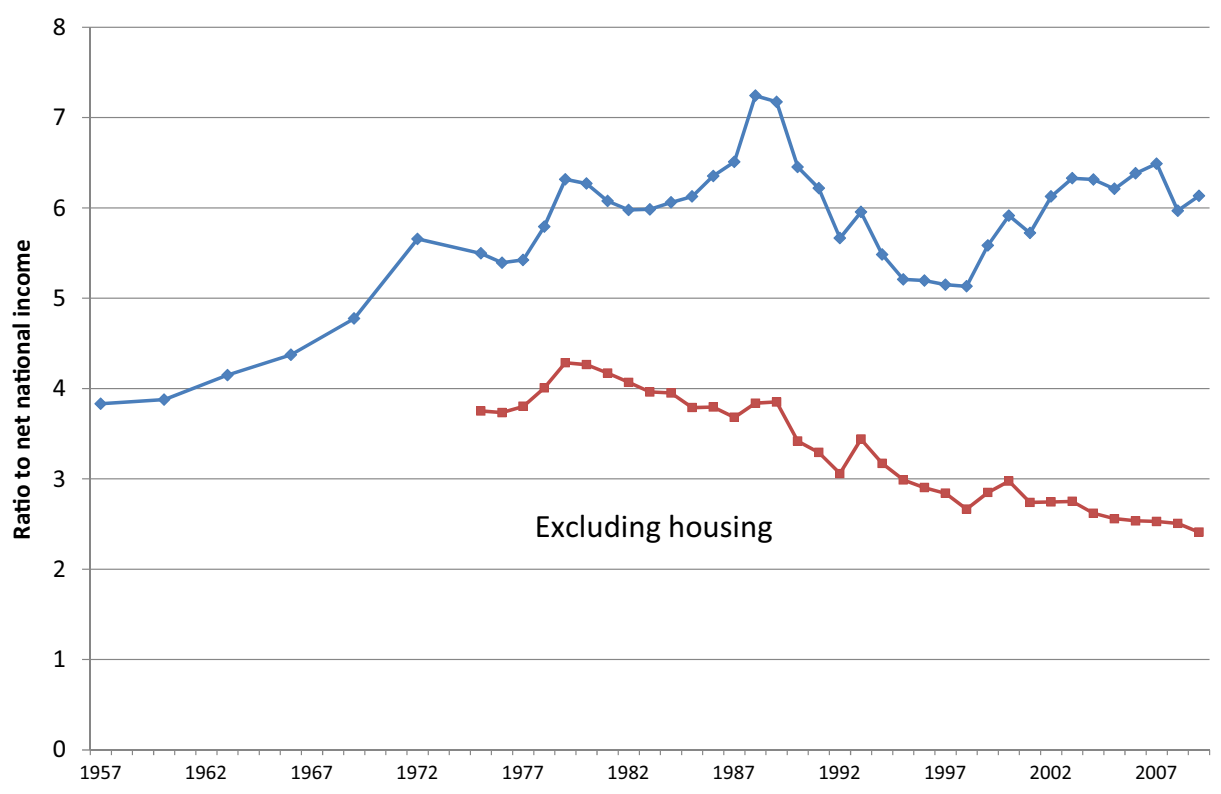

Fig. 3 National wealth in the United Kingdom from 1957 to 2010, including and excluding housing wealth, as ratio to net national income 


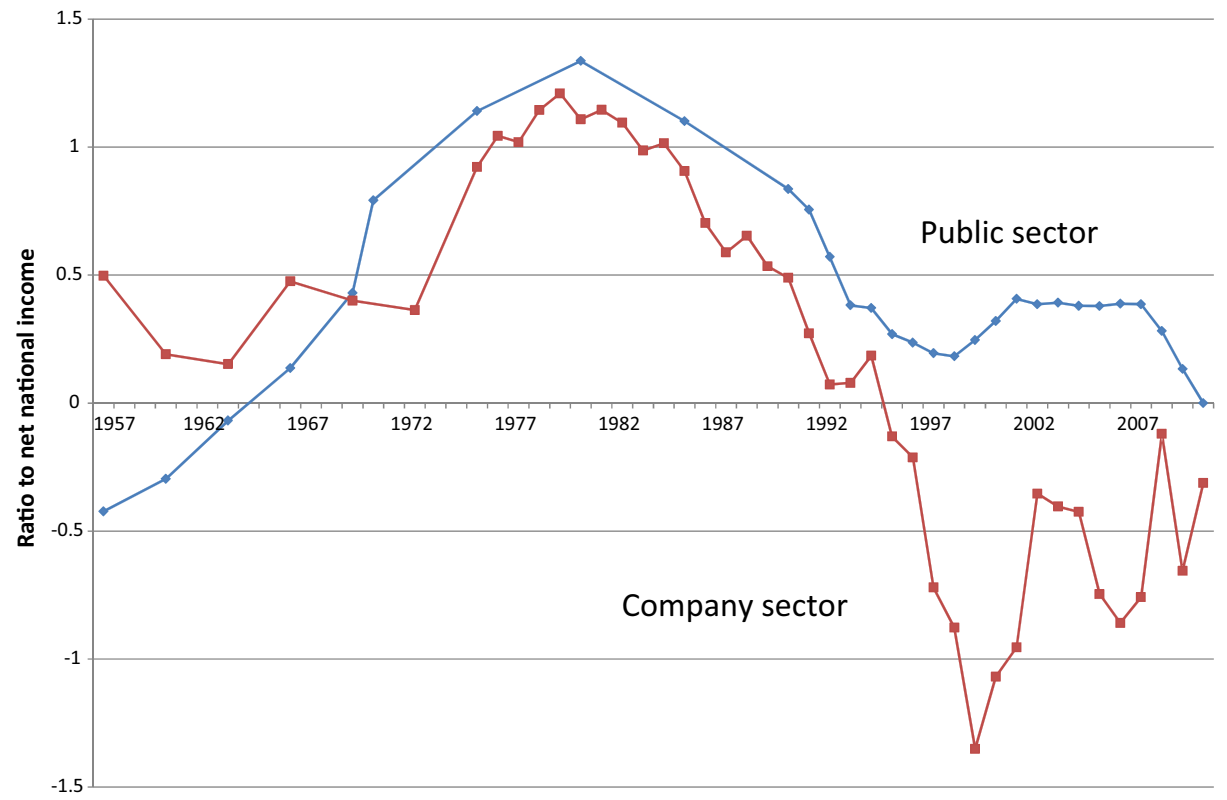

Fig. 4 Net worth of the public sector and the company sector in the United Kingdom from 1957 to 2010, as ratio to net national income

shares on the stock market fell considerably short-at that time-of the value placed on the company assets, net of liabilities. Treating the company shares as liabilities, the sector had positive net worth. Or, the ratio of market capitalisation to the value of assets was less than 1 (later, this ratio became known as Tobin's q). As discussed by Piketty (2009, Data Appendix, Part I, pages 33-36), the implications of the recorded positive net worth depend on its source. In the case of the US, it has been suggested by Wright (2004) that there has been a systematic over-valuation of company assets, as a result of the use of a perpetual inventory method. On the other hand, to the extent that the difference represents a sustained departure of asset prices from their underlying value, then we may need to take them into account. Long ago, Clay pointed out to the "concealed assets of Joint Stock Companies which are not fully represented in the Stock Exchange quotations of their stock" and went on to say that "these should be added, probably in the main, to the estimated amount of the capital in the hands of persons in the higher ranges of fortunes" (1925, page 80). As may be seen from Fig. 4, the net worth of the company sector went from substantially positive at the end of the 1970s to substantially negative at the turn of the century, where "substantial" means of the order of magnitude of total net national income. It has since returned close to zero, following, inversely, the ups and downs of the stock market. Expressed as a percentage of net national income, the fall from 1979 to 2010 was some 1.2, or around half the increase in the personal wealth-income ratio over that period.

The other important component is the balance sheet of the public sector. Net worth (not taking account of pension liabilities) is shown in Fig. 4. During the period before 1979, the public sector moved from a position where the national debt exceeded the value of assets by an amount of around half national income to a positive position, with a wealth-national income ratio of 1.3. In the next 30 years, the net worth of the state declined back to zero. In effect, the state transferred title in much of its real assets to individual households: the state 
net worth fell by an amount equal to some half of the increase in the personal wealth-income ratio over this period.

To sum up, the rise in national wealth in the first part of the post-war period was associated with increased net worth in the corporate and public sectors; in the second half of the period, these gains were, at least in part, transferred to the personal sector. Both corporate and public net worth were transferred to future generations, but the inheritance takes a different form-with different distributional consequences-now that the wealth is in the hands of the personal sector.

\section{Inheritance in the UK: Sources and methods}

Economic advantage is passed on from generation to generation in several ways, of which the most important is probably human capital. Here we are concerned with the transmission of material wealth such as real property, cash, financial assets, and company shares. Transfers may be made at death in the form of estates, or made as gifts inter vivos. Our aim is to measure the annual total of such transfers. The flows are gross flows, that is, we do not treat gifts given (or estates left) as negative entries. Where, for example, a person receives an inheritance of $X$ from a parent and immediately transfers this to a child as a gift inter vivos, this counts as a total transfer of $2 X$.

Our concern is with the aggregate of transfers, not their distribution. It is quite possible that estates are left, not to children, but to more distant relatives or indeed persons not related. A small but significant amount is left to charities (Atkinson et al. 2017). All of these transfers are counted here as inter-generational transfers. At the same time, transfers do not necessarily go from generation $t$ to generation $t+1$. Wealth can be transferred sideways to another member of the same generation or could skip a generation. The latter would cause the extent of wealth transfers to be under-stated. An investigation into estates arising from deaths in the UK in 2000/01 (reported on HMRC - Her Majesty's Revenue and Customs - website, Table 12.9) suggested however that grandchildren received a relatively small proportion of the bequests by value: 3.6 per cent (of the total excluding transfers to charities).

The most common "sideways" transfer is from husband to wife or vice versa. Ideally, we should like to exclude such within-generation transfers (including those from brother to sister or cousin), but this is not always possible, and to this extent the degree of intergenerational transfer is over-stated. The investigation into estates arising from deaths in the UK in 2000/01 showed that a large part of the estates left by married men ( 82.0 per cent) and married women (72.2 per cent) was left to the spouse (in these calculations, charitable transfers have again been omitted). ${ }^{1}$ These inter-spousal transfers accounted for 17.9 per cent of the value of transfers in that year. This is rather higher than the 10 per cent reported for France by Piketty (2011, footnote 36). The percentage passing to children was 49.2 per cent, which is quite a lot lower than the 70 per cent reported for France. In the UK, "other relatives" received 19.0 per cent, and "strangers in blood" 10.3 per cent. The estimates of Karagiannaki (2011a, Tables 1 and 2) give higher figures for inter-spousal transfers,

\footnotetext{
${ }^{1}$ A small-scale study carried out in 1981 produced similar results (Inland Revenue Statistics 1984, Table 4.7). Of the estates left by married men, 83 per cent by value (before duty but after subtracting charitable bequests) was left to the spouse, and 74.5 per cent for married women. Overall, men left 32.4 per cent, and women 42.8 per cent, to children or grandchildren.
} 
averaging 30 per cent over the period 2002-2005, which she finds compares well with the survey reports of inheritances.

\subsection{Estate statistics}

The transfer of wealth at death has long been the subject of taxation. Our period opens with the enactment of the modern Estate Duty (ED) in the 1894 Harcourt Budget that unified death duties on personal and real property. Estate Duty was replaced by Capital Transfer Tax (CTT) in 1975, and that in turn was replaced by Inheritance Tax (IHT) in 1986. The information used here comes from the published administrative data for these three taxes covering years since 1896 to 2008. Up to 1973, the data cover Great Britain (i.e. England, Wales and Scotland), thus avoiding any discontinuity when the (now) Republic of Ireland left the United Kingdom in 1921..$^{2}$ The sources are shown in Table 1. It should be noted that the period covered is much shorter than that for France-113 years, compared with 183 years-but that there are fewer missing observations: 13, compared with 49. In particular, the regular collection of estate data stopped in France in 1964, and the information used by Piketty (2011) for subsequent years comes from samples of the tax returns taken for the years 1977, 1984, 1987, 1994, 2000 and 2006. The last 45 years are better covered in the UK.

The "raw" estate information has to be corrected:

- to take into account estates below the tax threshold ("non-filers");

- for under-valuation or exemption of certain classes of assets;

- to take into account wealth transferred before death: gifts inter vivos.

The addition of the wealth transferred by non-filers is of minor importance (although it smoothes out the abrupt change when there is a large increase in the tax threshold in 1946), but the other two elements are potentially larger.

The three elements are discussed in turn. Considerable use is made of the adjustments applied in studies of the distribution of wealth amongst the living. At the same time, it should be noted that not all these adjustments are relevant, given that our focus here is on the transmission of wealth between generations. For example, these studies adjust by adding back amounts paid in funeral expenses (Atkinson and Harrison 1978, page 299), but these are genuine deductions from the amount transmitted and so no such correction is made here. In the same way, adjustments are made for joint property, such as a house, passing on the death of one spouse to the other. Since we would like in principle to exclude such sideways transfers, no such adjustment is made here when calculating transmitted wealth.

\subsection{Non-filers}

The estate returns today in the UK cover some 45-50 per cent of the number of deaths of persons aged 20 and over-see Fig. 5. This is a rather smaller percentage than the 65 per cent reported by Piketty for France (2011, page 1097), but it is not too different. On the other hand, there has been considerable variation in the coverage of the statistics over time. This reflects both changes in the exemption level and changes in statistical practice. When the modern Estate Duty was introduced by Harcourt in 1896, some 15 per cent of estates were liable for tax. Since the threshold remained at $£ 100$ from 1896 to 1945 , the proportion rose steadily, reaching 40 per cent at the end of the Second World War. The threshold was then increased sharply to $£ 2,000$, and, as a result, the proportion liable for tax fell to around

\footnotetext{
${ }^{2}$ Although it should be noted that the national income figures used as a denominator relate to Great Britain plus Northern Ireland.
} 


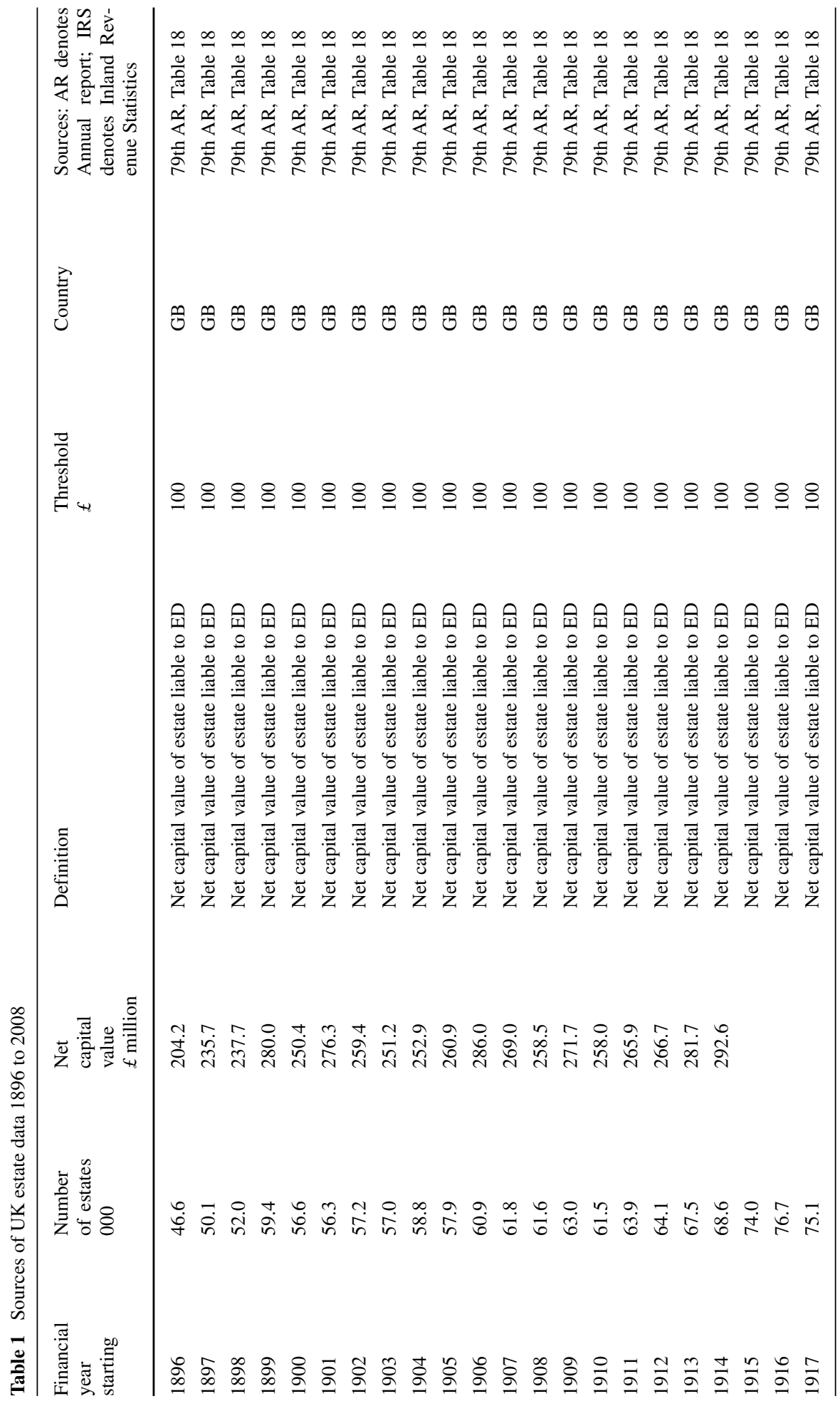




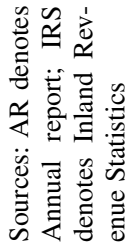

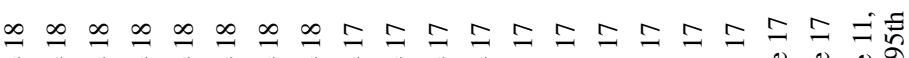

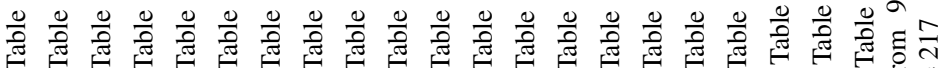

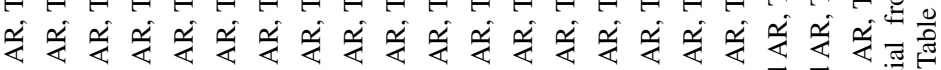

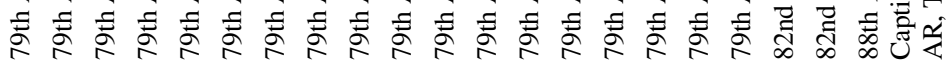

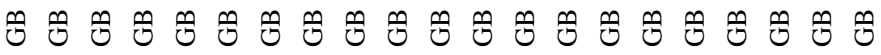

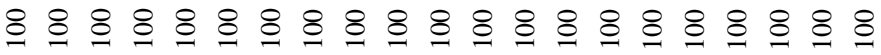

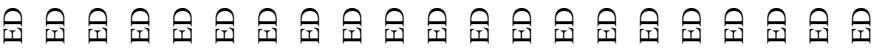

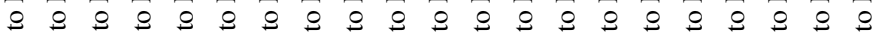

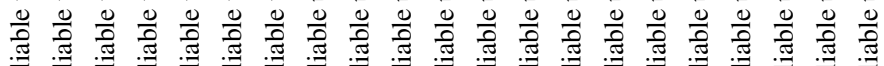

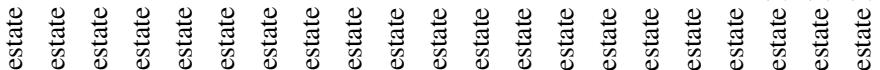
tᄒ

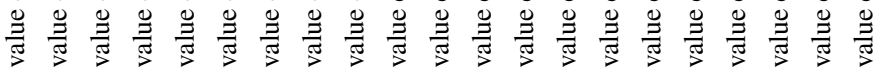
音

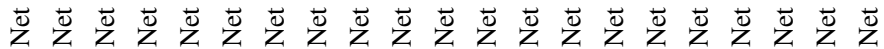

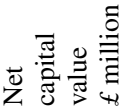

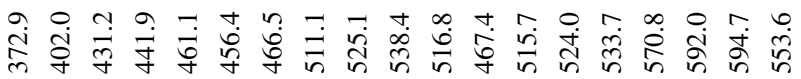

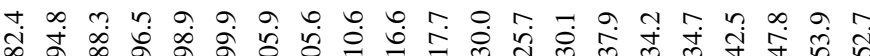

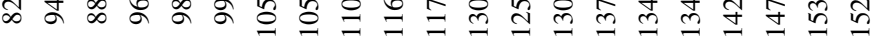









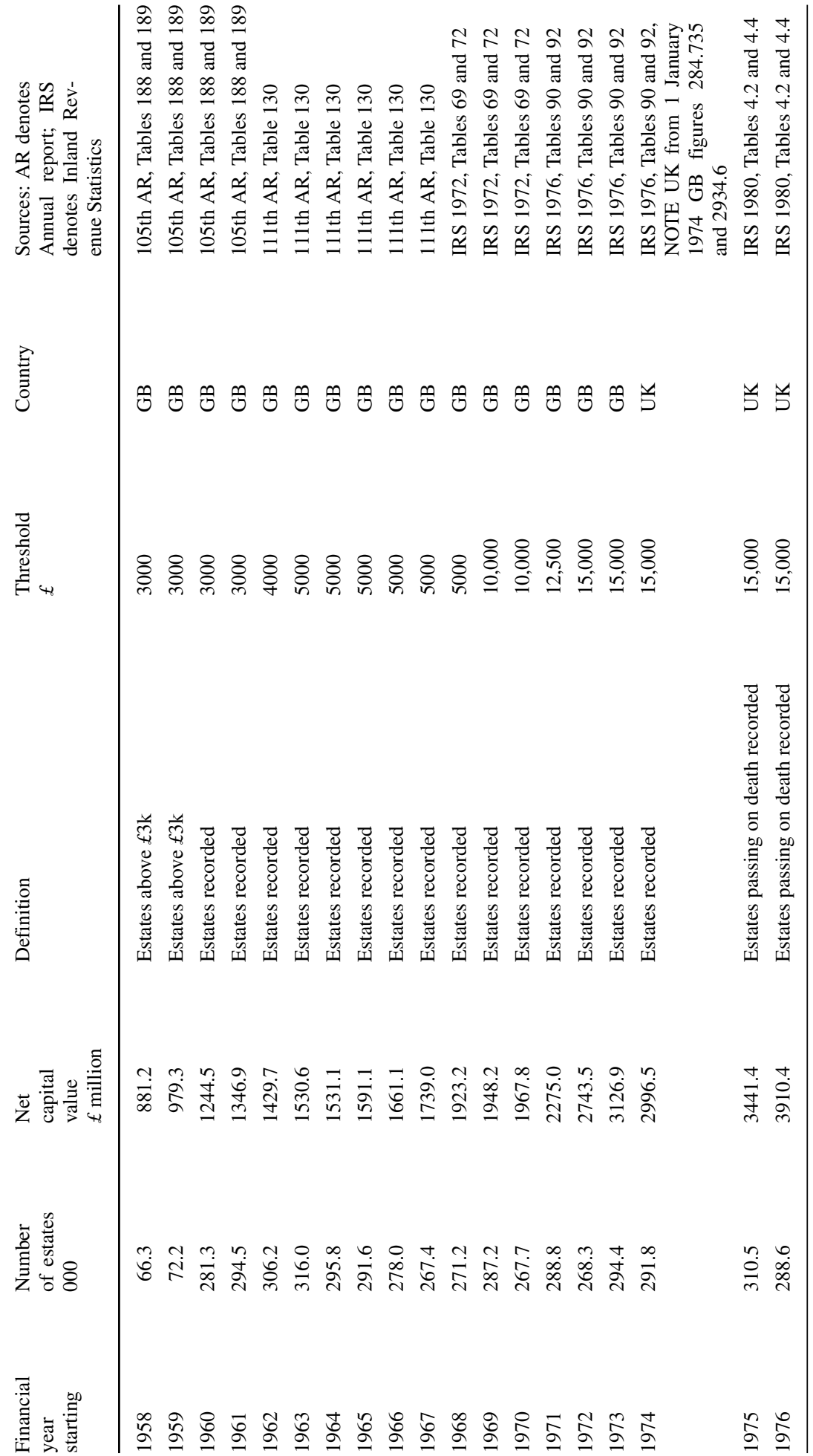




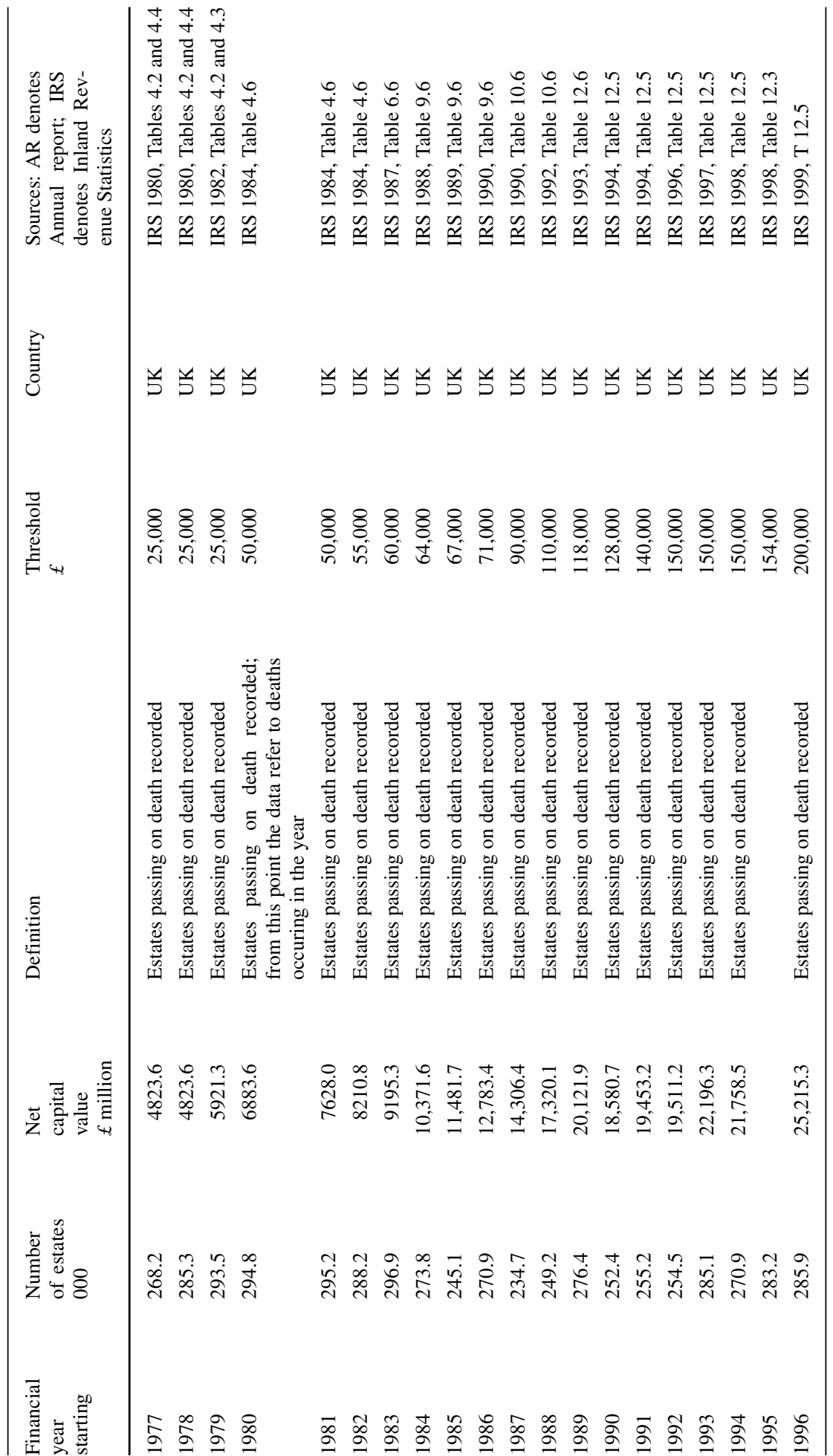




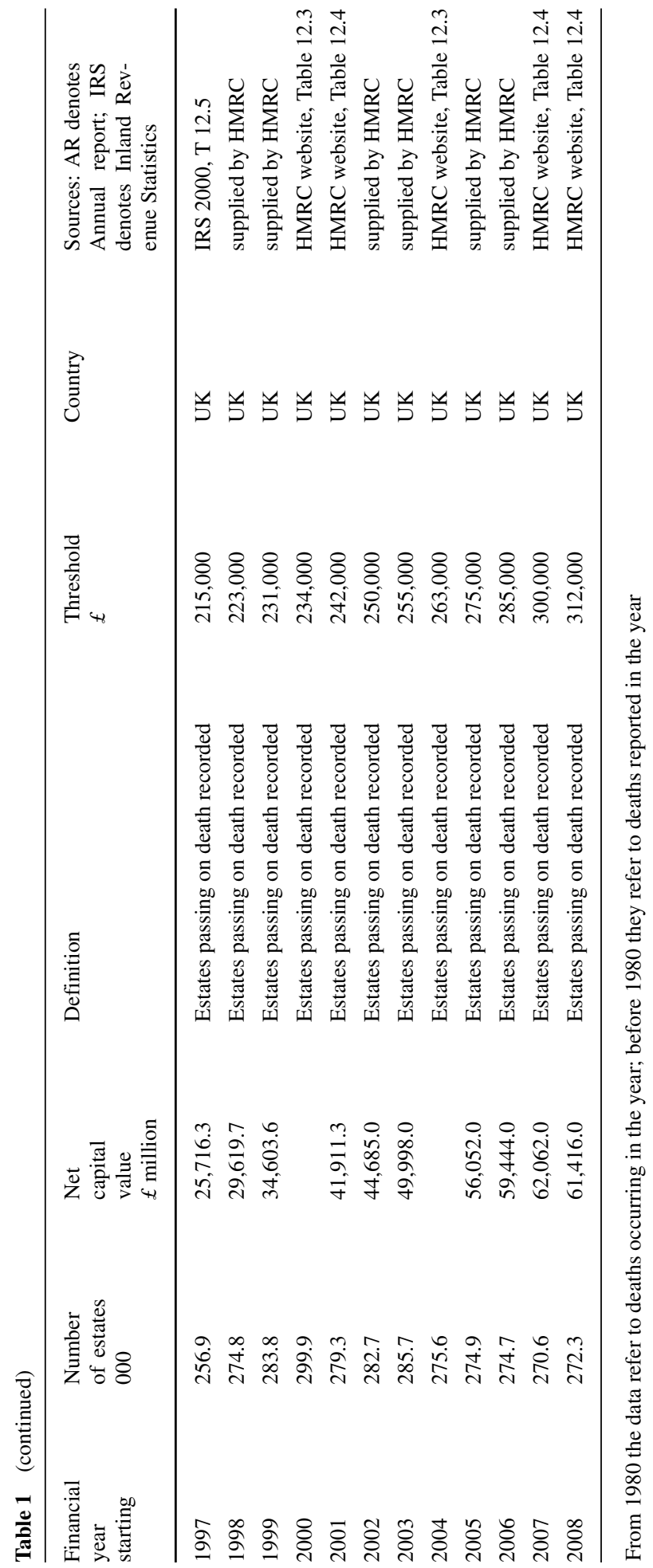




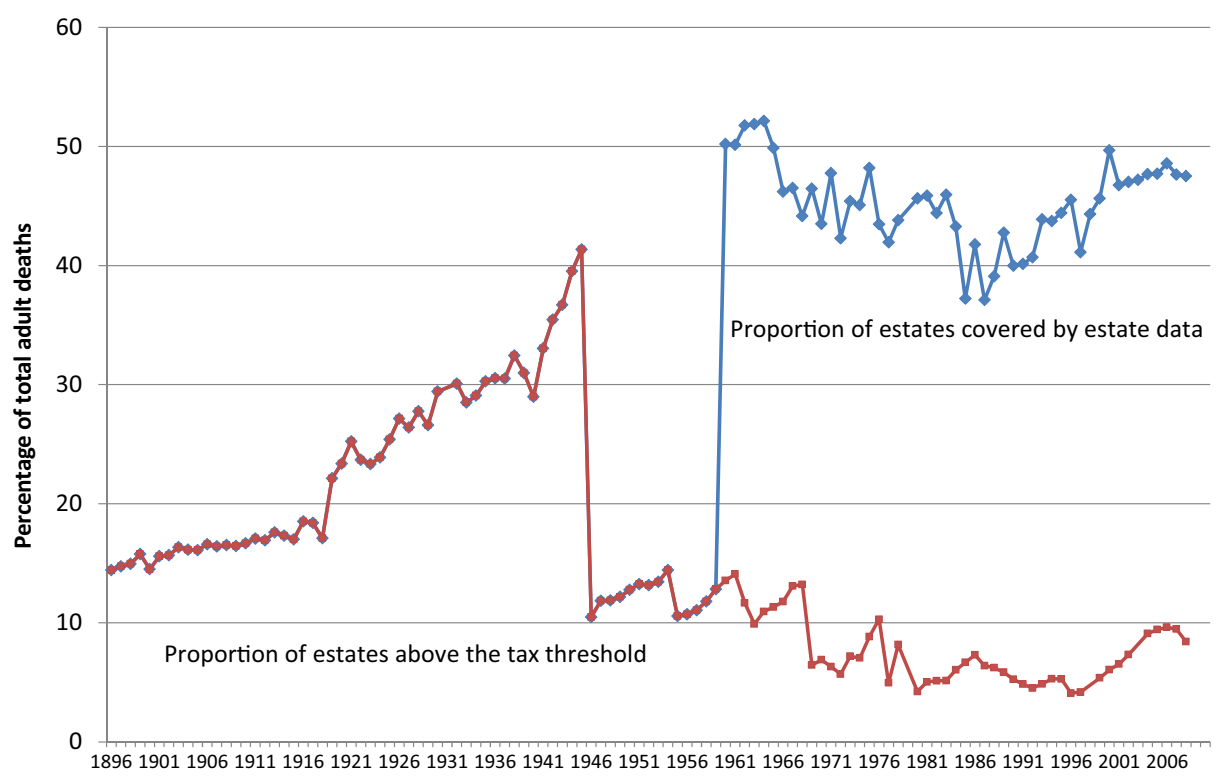

Fig. 5 Coverage of estate data and estate tax in Britain from 1896 to 2008

10 per cent. ${ }^{3}$ There was then a downward trend until the mid-1990s. ${ }^{4}$ On the other hand, from 1960, the statistics cover all estates brought to the attention of the authorities, and this gives a much larger proportion-between 40 and 50 per cent. The estates covered are those that are dutiable and those where there is a grant of representation (grant of confirmation in Scotland). 5

There are therefore, in the period since 1960, around half the estates missing, referred to here as the "excluded population" or "excluded estates." What is their wealth? The tax authorities (previously the Inland Revenue (IR), now HMRC) have in recent years sought to reconcile the estimates of wealth obtained from by multiplying up the estate data with the figures given in the national balance sheets (for example Table 13.3 on the HMRC website, archive tables). For 2005, the estimated wealth of the excluded population was around a quarter of the recorded wealth, but the greatest part of this was accounted for by property held jointly (typically where a couple own a house jointly). Since we are not concerned here with such "sideways transfers," we have considered only the "small estates", which are some 2 per cent of the recorded wealth. The figures are linearly interpolated where there are no IR/HMRC estimates.

\footnotetext{
${ }^{3}$ The sharp reduction in the number of estates covered is shown in Table 216 in 95th Inland Revenue Annual Report (AR), where the number for Great Britain falls from 204,000 to 53,000.

${ }^{4}$ As is demonstrated by Hills and Glennerster (2013), the RPI-adjusted threshold varied around a constant real level until the late 1980s and then began to rise (see their Figure 8.1). As they stress, the threshold exhibited considerable variation relative to house prices, to which it became linked since October 2007. This led to variation in the proportion of estates above the threshold - see Fig. 5.

5 The grant is the legal document that allows the executors or administrators to deal with a deceased person's estate.
} 
In order to go back to years before 1971 (the earliest IR estimate), we make use of the estimates of the wealth of the excluded population made by Atkinson and Harrison (1978). We link to the IR/HMRC series the central estimates for 1923 to 1972 of Atkinson and Harrison (1978, Table VI.1, column B3), extended to 1981 in Atkinson et al. (1989). ${ }^{6}$ We have adjusted the England and Wales estimates (for 1923 to 1938) to a Great Britain basis by simply multiplying by the ratio of the Great Britain to England and Wales populations. The Atkinson and Harrison estimates are not fully appropriate, as they include jointly held property, although this was then smaller in value, since the rate of owner-occupation was lower. The estimates have the advantage that they make provision for the "jump" in the series between 1959 and 1960, allowing for the much larger proportion, some 90 per cent, not covered between 1946 and 1959. The estimates were based on an exercise that involved examining, by asset type, the implications of the higher level of exclusion. This procedure was based on the work of earlier researchers such as Clay (1925), Campion (1939), and Lydall and Tipping (1961). The calculations made here of the wealth of the excluded population for the period 1896 to 1922 follow the approach of Clay (1925) for 1912 and 1921. The methods are described in the Appendix.

We have now to go from the wealth of the excluded population to the amount bequeathed in any one year. This depends on the mortality amongst the excluded population, about which we have no direct information. We have to apply the reverse of a mortality multiplier. For the present, a simple multiplier of 30 has been assumed to apply throughout the period. The addition for non-filers is small in most years, but it does make a significant difference for the period from 1946 to 1959, when the data did not cover any estates below the threshold. The corrected series gives a more accurate picture of the changes over time.

\subsection{Under-valuation or exemption of certain classes of assets}

The adjustments considered here concern (i) the possible under- or over- valuation of assets transferred through inheritance, and (ii) the omission of assets through tax avoidance. No account is taken of evasion. In 1967, Revell commented that "most people would probably agree that [evasion] is at a low level in Britain-if only because the legal methods of avoidance are so many" Revell (1967, page 112). ${ }^{7}$ Both valuation and omission are affected by the changing forms of capital taxation, which impact on both behaviour and the statistical recording. In what follows, reference is made to some of the relevant provisions, but no attempt is made to follow all the changes that have taken place over more than a century.

There are several reasons why the valuation may depart from that needed here. The Inland Revenue (HMRC) has identified these in their studies of total personal wealth and their reconciliation of the wealth estimates obtained from estate data with the national balance sheets. As noted above, in some cases the adjustments do not apply here. For example, they adjust life policies on the grounds that the estate data value the policies at the amount paid on death, whereas in the hands of the living their value is less. Here we are interested in the sum passed on, so that the estate valuation is correct.

\footnotetext{
${ }^{6}$ The gaps in the series from 1931 to 1935,1937 , and 1939-1941, are filled by linear interpolation. The gap from 1946 to 1949 was filled by extrapolating backwards the 1950 figure on the basis of the change in the total personal wealth series.

${ }^{7}$ At the time of the introduction of the modern Estate Duty there was much discussion of the risk of increased evasion. The fall in revenue that had been feared did not materialise, and the Inland Revenue noted in in its Annual Report of 1895 that "the fears of evasion ... were exaggerated" (38th AR, page 52).
} 
Certain of the adjustments for valuation that are relevant here affect specific classes of asset. For example Inland Revenue research into estates below the threshold found that the value of dwellings in such estates had been underestimated by some 15 per cent, leading to an overall increase of some 10 per cent in the valuation of houses (Central Statistical Office 1978, page 46). Or the adjustment may affect several asset classes. For example, the valuation has been affected by the time lags between death and the appearance of the estates in the statistics. Given a general tendency for asset prices to rise, this leads to an under-statement. The Inland Revenue estimated that for the years 1965 to 1975, the average under-statement was some 2.5 per cent (Central Statistical Office, 1978, page 43). ${ }^{8}$ The official statistics switched to a "year of death basis" with effect from 1980 (see Inland Revenue Statistics 1984, page 42).

The second type of adjustment is for property that does not have to be notified for probate. Under Estate Duty, in addition to small estates, and jointly-owned property passing on death, this included most property held in discretionary trusts, accumulation and maintenance fund property, and property held in settlements on a surviving spouse (Dunn and Hoffman 1983, page 39). Certain assets are not included in the estate because they are taxed separately, for example the special provision introduced in 1909 whereby growing timber is not taxed until it is sold. It should be noted that certain assets attract a lower rate of duty, such as farm or business assets, but the full value is in principle recorded in the statistics. The geographical coverage may lead to certain assets being excluded, such as immovable property situated overseas until the Finance Act 1962, or incorrectly included, such as certain property belonging to persons domiciled in other countries. In addition, from 1896 until 1914, Settlement Estate Duty was in force. Settled property (property held on trusts) on which duty had been once paid was not liable a second time and, as a result, a substantial amount of settled property was missing from the estate statistics.

Faced with this variety of problems, it is not easy to estimate correction factors, but the research undertaken by the Inland Revenue provides a valuable basis for the years since 1971. They have regularly supplied tables showing the different steps in going from the multiplied-up net worth of the personal sector as identified on the basis of the estate data to the balance sheet estimates. Here I have not taken the adjustments for life policies, pension rights, consumer durables, or small estates (already included above), or joint property (for the reason explained above). In terms of the adjustments listed in Central Statistical Office (1978, page 42), I have taken adjustments 1 to 4 (later labelled "under-recording") and 7 ("excluded trusts"). These adjustments have varied as a percentage of the total identified wealth, but were around 15 per cent from the 1970s through to the early 1990s, when they rose to around 25 per cent. It has to be recognised that the adjustments apply to estimated wealth, and do not necessarily apply to estates. The allocation depends on the age/gender mix (see Dunn and Hoffman (1983)). This means that any attribution is at best approximate. Rather than using the figures for individual years, I therefore simply assume an adjustment of 15 per cent from 1971 to 1995 and 25 per cent thereafter. For the excluded trusts, the early Inland Revenue estimates were of the order of 5 per cent, but following the work of Robson and Timmins (1988), they arrived at estimates which were "much lower than those previously used, but are considered to be more accurate" (Inland Revenue Statistics 1988, page 85). The revised estimates were some 1 per cent of identified wealth, and this figure has been used throughout the period.

\footnotetext{
${ }^{8}$ Insofar as the adjustment is to an end of year basis, this is not appropriate for our purposes.
} 
For earlier years, we have to turn to the limited estimates that have been made in the past. It should be noted that the precise basis for these estimates is not always apparent. Campion (1939, page 18) gives an estimate for 1911 of $£ 51-£ 59$ million for settled property passing at death excluded from the estate duty returns, or some 20 per cent of total estates in that year. The estimate of Campion for 1926-8 is much lower, as we would expect given the ending in 1914 of the separate Settlement Estate Duty: $£ 20-£ 30$ million, or some 5 per cent. In their estimates for 1954 , Lydall and Tipping added to their total of $£ 40$ billion for personal wealth a further $£ 1$ billion ( 2.5 per cent) for discretionary trusts (Lydall and Tipping 1961). For 1961, Revell (1967, pages 137 and 138) estimated a much smaller $£ 350$ million (0.5 per cent of $£ 78$ billion), which is, interestingly, closer to the 1 per cent taken here for the 1970s. There are some reasons for supposing that the "under-recording" adjustment would have been smaller in the past, given the lower rate of owner-occupation, and the lower rate of asset price increase. In view of this, I have simply applied a 10 per cent adjustment for both elements (under-valuation and exempt settled property) for the period 1915-1971, and 20 per cent for $1896-1914$.

\subsection{Gifts inter vivos}

Gifts inter vivos are an obvious route to avoid death duties, and gifts made in a period prior to death have for this reason been taxed under death duties. The gross amount of gifts began to be reported in the Estate Duty statistics from $1897 .{ }^{9}$ The period covered was initially a year, but was extended in 1910 to three years. The period for which gifts were subject to duty was increased in 1946 to five years, and in 1968 to seven years. To further complicate matters, the Finance Act 1960 provided that where gifts were made in the third, fourth and fifth years before death, their value should be reduced for tax purposes by 15, 30 and 60 per cent respectively. Estate Duty was replaced by Capital Transfer Tax (CTT) in 1975, which extended the tax to all lifetime transfers (those made after 26 March 1974). This provision was short-lived, being replaced by a ten year period, which was in effect from 27 July 1981 to 18 March 1986. The Finance Act 1986 introduced the current Inheritance Tax, replacing CTT, levied on assets left at death and gifts made within seven years of death, with the charge tapered depending on the period between the gift and death.

The incomplete taxation of gifts inter vivos means that the UK data on gifts are much less complete than those in France, where in principle all of them are recorded. This seriously limits the extent to which we can correct the estate figures for the missing gifts inter vivos. At the same time, a number of attempts have been made, using different methods, to estimate the extent of gifts inter vivos in the UK. The researchers have all recognised the considerable limitations of the estimates, but they provide some basis for quantification.

The first attempt, to my knowledge, is that of Wedgwood $(1929,1939)$. He made use of the fact that "voluntary dispositions" of certain classes of asset were taxable under the Stamp Duties. This applied independently of the time when they were made, so in principle all gifts in the relevant classes were covered. But the partial coverage and exemptions meant that the estimate based on gifts paying Stamp Duty was a lower bound. As put by Wedgwood, "we know what it must exceed, by referring to the figures of gifts taxed for Stamp Duty"

\footnotetext{
${ }^{9}$ Details are provided in Sandford (1971). He points out that the early figures were gross amounts but that net amounts were also given from 1919 to 1930. From his Table B1, it may be seen that the net and gross amounts are very close, and no distinction is drawn here.
} 


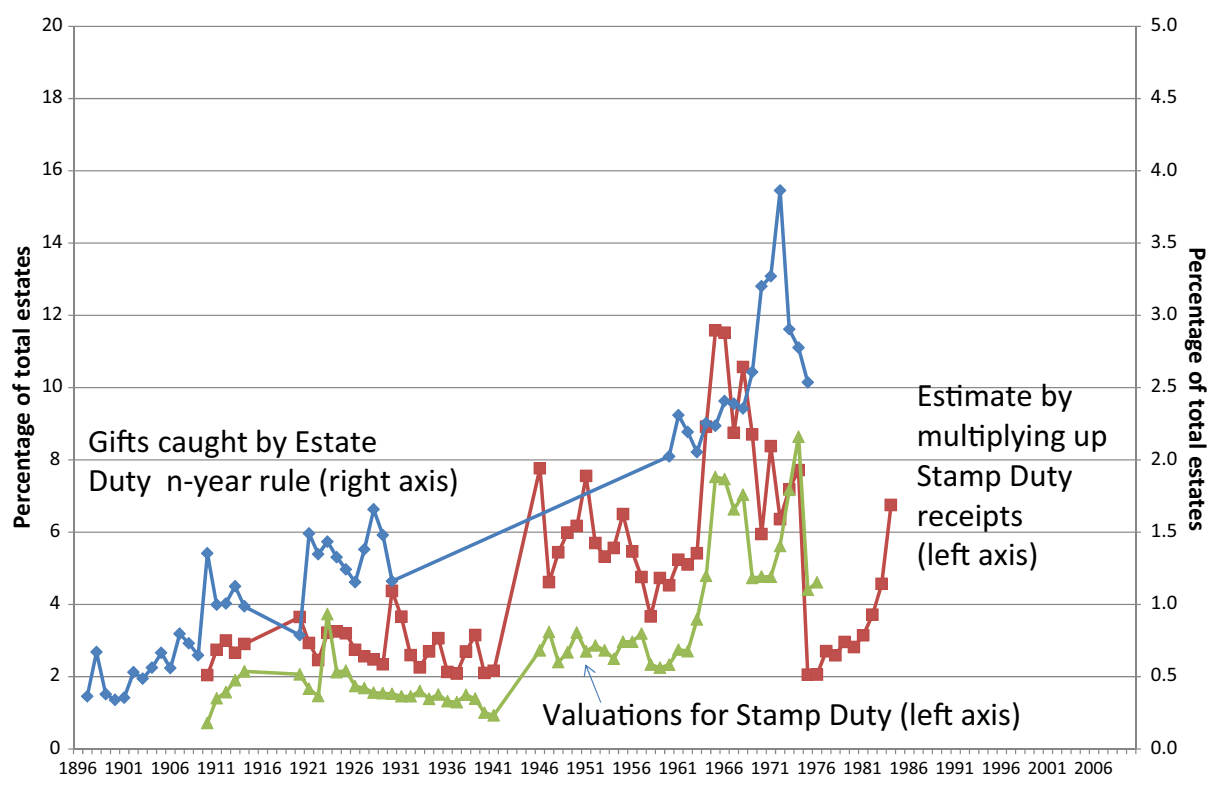

Fig. 6 Estimates of gifts inter vivos based on Stamp Duty in the United Kingdom from 1896 to 1985

Wedgwood (1929, 1939, page 245), but we do not know how much more is transferred in exempt forms, which include British Government stocks, cash, bearer bonds, household goods, and transfers below the Stamp Duty exemption limit.

The charge under Stamp Duty was introduced in the Finance Act 1910, and the data therefore start in 1910. The charge on gifts was abolished with effect from 1985. The series therefore covers a considerable part, but not all, of the period. The data have been used by Whalley (1974), following the suggestions of Prest (1973), to make estimates for the period 1960 to 1961, and here I have used the full run of available years from 1910 to 1984 - see Fig. 6. Unfortunately, the data do not record the total transferred but the net receipt of duty. It is therefore necessary to gross-up the recorded amounts. The procedure used here, as in Whalley (1974), is to assume the "standard" rate of duty, which was 1 per cent at the outset, but which has been 2 per cent in two periods. Grossing up by a factor of 100 or 50 does however under-state the total, since there were reduced rates on smaller transfers. Some check can be made from a second set of figures, published up to 1976, of the valuations undertaken by the Valuation Office in relation to the Duty. These valuations however are only made for certain classes of transfer, so that they would understate the total. The results in Fig. 6 suggest that the valuation-based numbers move over time in a similar manner to the grossed-up duty estimates, with the valuation numbers (usually) below the grossed-up estimates. This is re-assuring. Finally, we should note that the estimates are of total gifts, some of which would fall within the period for which they would be taxable (and hence would already have been included). Whalley made corrections for the years 1960 to 1965 to subtract those gifts that were subsequently caught by Estate Duty (and therefore have already been counted in the estate totals). Around a quarter were taxed under the 5 year period, and around a third for the 7 year period. Overall, Whalley concluded that a minimum of 10 per cent of wealth passes via gifts and that a minimum of 7 per cent avoided Estate 
Duty. He goes on to say that "one certainly cannot exclude the possibility of the stamp duty statistics only capturing one-half of gifts actually made" (1974, page 642).

The second method uses the data on gifts "caught" by Estate Duty under the n-year rule, for which gifts become taxable if death occurs within $\mathrm{n}$ years. This method was proposed by Tait (1967, Appendix II), and applied in Atkinson (1972, page 127) to estimate that the gifts avoiding Estate Duty in 1966 amounted to $£ 350$ million, adding around a fifth to the total transferred. As was noted by Whalley (1974, page 642), such an estimate would be consistent with the Stamp Duty approach if the latter were capturing only a half. We should also note that Sandford, studying the development of the amount of gifts caught by the rule from 1898, expressed as a percentage of the total estates, concluded that "there has clearly been a secular upward trend in the amount of giving since the introduction of estate duty" (1971, page 87). The same conclusion was drawn by Horsman (1975). For the period 1960 to 1971 he found "a growing tendency for wealth-holders to try to avoid duty by means of gifts" (Horsman 1975, page 522). In Fig. 6, the Estate Duty-based figure shows the amount of gifts caught by the n-year rule, expressed as a percentage of total estates. The effect of the extension of $\mathrm{n}$ from 1 to 3 can be seen from the jump in 1910, and from 5 to 7 from the rise after 1968. Unfortunately, the published Estate Duty statistics do not show the gifts caught by Duty for the period 1931 to 1959 .

The Estate Duty method multiplies up the total recorded gifts to allow for those where the donor did not die within the specified period. The central objection to the calculations of Tait and Atkinson, as noted by Sandford (1971, page 87n), is that they applied a single arbitrary mortality multiplier to the estate totals. Horsman (1975) was able to use the Inland Revenue multipliers appropriate for the relevant age/sex group. He found that the total gifts were $£ 413$ million in $1967 / 8$ and $£ 396$ million in $1968 / 9$, implying overall mortality multipliers of 9.9 and 8.7 , respectively. They also represented 23.7 and 20.6 per cent of the total gross value of estates in the two years. Horsman went on to estimate that the amounts of gifts avoiding Duty were $£ 352$ million and $£ 322$ million (20.2 per cent and 16.8 per cent of total gross estates).

The vertical scales in Fig. 6 are such that, if the gifts caught by Estate Duty were multiplied by 4 , then they would be comparable with the scale for the gift estimates based on Stamp Duty. If the latter are under-stated by a factor of 2 , then the two sets of figures would be broadly in agreement if the appropriate mortality multiplier were 8 (i.e. $4 \times 2$ ). This would be close to those derived by Horsman. It should be noted that this takes no account of the variations in the period for which gifts were subject to duty.

Taking the evidence from both these sources in the round, there seems therefore to be grounds for adding to the estate totals a figure of around 15-20 per cent in the late 1960s. This was indeed the conclusion of the Royal Commission on the Distribution of Income and Wealth: "the Inland Revenue statistics of estates may underestimate the amount of wealth passing by as much as 15-20 per cent because of the omission of gifts falling outside the 7-year period" (1977, page 279). The time-path in Fig. 5 suggests that the adjustment in the 1950 s would be smaller-around 10 per cent-and more like 5 per cent before the Second World War. The evidence for recent years is less easy to interpret, in view of the changes in taxation. There is however a further source - sample surveys that have been exploited in Karagiannaki (2011b). In particular, making use of the Attitudes to Inheritance Survey, conducted in 2004, she estimates that aggregate gifts are about 10 per cent of total inheritances. In view of these findings, I make the - approximate-adjustments for gifts inter vivos not captured in the estate figures: 5 per cent addition prior to 1945,10 per cent from 1945 to 1959,15 per cent for the 1960s and 1970s, and 10 per cent after 1979. It is 
however quite possible that the adjustment under-states the extent of gifts inter vivos. As is noted by Karagiannaki and Hills, "none of the available data sources appears to capture the whole picture" (2013, page 116).

\section{A return of inheritance in Britain?}

The end results of the calculations described in the previous section are given in Table 2, which shows the aggregate wealth transmitted each year over the period 1896 to 2008. In considering these results, it is important to bear in mind the number of assumptions made in arriving at the estimates, and the qualifications that surround them. The figures over-state the intergenerational transmission of wealth insofar as there are sideways transfers; they under-state insofar as there are transfers that skip generations. The adjustments for undervaluation, for exempt property and for gifts inter vivos are all very approximate. The extent of gifts may well be under-stated.

The time-path of transmitted wealth is illustrated in Fig. 7. This demonstrates the major importance of inheritance before the First World War, when the adjusted total represented some 20 per cent when expressed relative to net national income. In the inter-war period, the adjusted total was around 15 per cent, falling to some 10 per cent after the Second World War, and then falling further to reach 5 per cent in the late 1970s. The question posed in the title of this section asks whether there has since been an upturn in inheritance. The answer depends on the standard of comparison. From the evidence summarised in Fig. 7, the ratio of bequests to national income has risen since 1977. The unadjusted ratio was 3.4 and rose to 5.8 in 2006, falling back after the financial crisis to 5.4 in 2008. The adjusted figure showed a rise from 4.8 in 1977 to 8.2 in 2006, a rise of more than 3 percentage points. On the other hand, this increase was more or less in line with the increase in personal wealth, so that Fig. 8 shows a downward trend until 1990, followed by a levelling-off. When people deny that inheritance has returned, then they may well have in mind the fact that it has not increased in relation to total wealth. In the US, for example, Wolff and Gittleman find "little evidence of an inheritance "boom." "[From 1989 to 2007] wealth transfers as a proportion of current net worth fell sharply ... by 10 percentage points" (2011, page 1 ).

The fact that bequests in the UK seem to have tracked personal wealth in recent decades does not however undercut the importance of this development. The rise relative to national income is what matters for the taxable capacity. At a marginal tax rate of a third, a rise of 3 percentage points would add 1 percentage point of national income to potential tax revenue, making a significant contribution to reducing the deficit. Moreover, as discussed in Section 2, the rise in personal wealth reflects, in part, the fall in the net worth of the public and corporate sectors, and this has implications for the distributional justice and for the economy. In the case of company shares, it could be argued that these were in the past under-valued. When a person passed on shares to their children, the underlying value of these shares was in the past greater than the stock market valuation. We should have imputed the net worth of the corporate sector to the holders of company shares. Seen in this light, part of the fall in bequests in the early 1970s may have been due to falling stock prices, with their counterpart in rising net worth of the corporate sector. To this extent, the answer may be, not that inheritance has returned, but that it never really went away.

On the other hand, as argued by Piketty (2009, Data Appendix, page 34), no such adjustment should be made where the fall in corporate net worth was simply a correction of an earlier over-valuation. And this argument does not apply to the net worth of the public 
Table 2 Estates as percentage of net national income in Great Britain (United Kingdom since 1974), with adjustments

\begin{tabular}{|c|c|c|c|c|c|}
\hline & $\begin{array}{l}\text { Unadjusted } \\
\text { estates } £ \text { million }\end{array}$ & $\begin{array}{l}\text { as \% national } \\
\text { income }\end{array}$ & $\begin{array}{l}\text { Corrected } \\
\text { for non-filers } \\
\text { as \% national } \\
\text { income }\end{array}$ & $\begin{array}{l}\text { Plus correction for } \\
\text { exempt assets and } \\
\text { undervaluation as } \\
\% \text { national income }\end{array}$ & $\begin{array}{l}\text { Plus gifts inter vivos } \\
\text { as } \% \text { national income }\end{array}$ \\
\hline 1896 & 204.2 & 14.8 & 15.2 & 18.1 & 18.9 \\
\hline 1897 & 235.7 & 16.5 & 16.9 & 20.2 & 21.0 \\
\hline 1898 & 237.7 & 15.7 & 16.1 & 19.3 & 20.1 \\
\hline 1899 & 280.0 & 17.6 & 18.0 & 21.5 & 22.3 \\
\hline 1900 & 250.4 & 15.3 & 15.7 & 18.8 & 19.5 \\
\hline 1901 & 276.3 & 17.1 & 17.6 & 21.0 & 21.8 \\
\hline 1901 & 276.3 & 17.1 & 17.6 & 21.0 & 21.8 \\
\hline 1902 & 259.4 & 15.9 & 16.3 & 19.5 & 20.3 \\
\hline 1903 & 251.2 & 15.7 & 16.1 & 19.2 & 20.0 \\
\hline 1904 & 252.9 & 15.9 & 16.4 & 19.5 & 20.3 \\
\hline 1905 & 260.9 & 15.7 & 16.1 & 19.2 & 20.0 \\
\hline 1906 & 286.0 & 16.2 & 16.6 & 19.9 & 20.7 \\
\hline 1907 & 269.0 & 14.5 & 14.9 & 17.8 & 18.5 \\
\hline 1908 & 258.5 & 14.6 & 15.1 & 18.0 & 18.7 \\
\hline 1909 & 271.7 & 15.1 & 15.6 & 18.6 & 19.4 \\
\hline 1910 & 258.0 & 13.8 & 14.2 & 17.0 & 17.6 \\
\hline 1911 & 265.9 & 13.6 & 14.0 & 16.7 & 17.4 \\
\hline 1912 & 266.7 & 13.0 & 13.4 & 16.0 & 16.6 \\
\hline 1913 & 281.7 & 13.2 & 13.7 & 16.3 & 17.0 \\
\hline 1914 & 292.6 & 13.6 & 14.0 & 16.7 & 17.4 \\
\hline \multicolumn{6}{|l|}{1915} \\
\hline \multicolumn{6}{|l|}{1916} \\
\hline \multicolumn{6}{|l|}{1917} \\
\hline \multicolumn{6}{|l|}{1918} \\
\hline \multicolumn{6}{|l|}{1919} \\
\hline 1920 & 372.9 & 7.3 & 7.7 & 8.5 & 8.8 \\
\hline 1921 & 402.0 & 9.5 & 9.9 & 10.8 & 11.3 \\
\hline 1922 & 431.2 & 11.6 & 12.1 & 13.3 & 13.9 \\
\hline 1923 & 441.9 & 12.5 & 13.0 & 14.3 & 14.9 \\
\hline 1924 & 461.1 & 12.5 & 13.1 & 14.3 & 14.9 \\
\hline 1925 & 456.4 & 11.5 & 12.0 & 13.2 & 13.8 \\
\hline 1926 & 466.5 & 12.4 & 13.0 & 14.2 & 14.9 \\
\hline 1927 & 511.1 & 12.8 & 13.4 & 14.6 & 15.3 \\
\hline 1928 & 525.1 & 13.1 & 13.7 & 15.0 & 15.6 \\
\hline 1929 & 538.4 & 13.0 & 13.6 & 14.9 & 15.5 \\
\hline 1930 & 516.8 & 12.7 & 13.3 & 14.5 & 15.2 \\
\hline 1931 & 467.4 & 12.8 & 13.4 & 14.7 & 15.3 \\
\hline 1932 & 515.7 & 14.5 & 15.2 & 16.7 & 17.4 \\
\hline 1933 & 524.0 & 14.4 & 15.0 & 16.5 & 17.2 \\
\hline 1934 & 533.7 & 13.6 & 14.3 & 15.7 & 16.3 \\
\hline
\end{tabular}


Table 2 (continued)

\begin{tabular}{|c|c|c|c|c|c|}
\hline & $\begin{array}{l}\text { Unadjusted } \\
\text { estates } £ \text { million }\end{array}$ & $\begin{array}{l}\text { as \% national } \\
\text { income }\end{array}$ & $\begin{array}{l}\text { Corrected } \\
\text { for non-filers } \\
\text { as \% national } \\
\text { income }\end{array}$ & $\begin{array}{l}\text { Plus correction for } \\
\text { exempt assets and } \\
\text { undervaluation as } \\
\% \text { national income }\end{array}$ & $\begin{array}{l}\text { Plus gifts inter vivos } \\
\text { as } \% \text { national income }\end{array}$ \\
\hline 1935 & 570.8 & 14.0 & 14.6 & 16.0 & 16.7 \\
\hline 1936 & 592.0 & 13.7 & 14.4 & 15.7 & 16.4 \\
\hline 1937 & 594.7 & 13.1 & 13.7 & 15.0 & 15.6 \\
\hline 1938 & 553.6 & 11.6 & 12.2 & 13.4 & 14.0 \\
\hline 1939 & 533.1 & 10.9 & 11.5 & 12.5 & 13.1 \\
\hline 1940 & 537.8 & 9.7 & 10.3 & 11.2 & 11.7 \\
\hline 1941 & 569.4 & 8.5 & 8.9 & 9.8 & 10.2 \\
\hline \multicolumn{6}{|l|}{1942} \\
\hline \multicolumn{6}{|l|}{1943} \\
\hline \multicolumn{6}{|l|}{1944} \\
\hline \multicolumn{6}{|l|}{1945} \\
\hline 1946 & 656.5 & 8.0 & 9.6 & 10.4 & 11.2 \\
\hline 1947 & 802.9 & 9.2 & 10.6 & 11.6 & 12.5 \\
\hline 1948 & 807.9 & 8.4 & 9.7 & 10.5 & 11.4 \\
\hline 1949 & 819.3 & 7.9 & 9.2 & 10.0 & 10.8 \\
\hline 1950 & 807.5 & 7.5 & 8.7 & 9.4 & 10.2 \\
\hline 1951 & 840.9 & 7.1 & 8.3 & 9.0 & 9.7 \\
\hline 1952 & 747.7 & 5.4 & 6.5 & 7.0 & 7.6 \\
\hline 1953 & 751.2 & 5.6 & 6.6 & 7.2 & 7.8 \\
\hline 1954 & 849.5 & 5.9 & 7.0 & 7.6 & 8.1 \\
\hline 1955 & 758.1 & 4.9 & 6.3 & 6.8 & 7.3 \\
\hline 1956 & 768.2 & 4.6 & 6.0 & 6.5 & 7.0 \\
\hline 1957 & 780.1 & 4.5 & 5.9 & 6.4 & 6.8 \\
\hline 1958 & 881.2 & 4.8 & 6.3 & 6.8 & 7.3 \\
\hline 1959 & 979.3 & 5.1 & 6.6 & 7.1 & 7.6 \\
\hline 1960 & $1,244.5$ & 5.9 & 6.3 & 6.9 & 7.8 \\
\hline 1961 & $1,346.9$ & 6.0 & 6.5 & 7.1 & 8.0 \\
\hline 1962 & $1,429.7$ & 6.1 & 6.6 & 7.2 & 8.1 \\
\hline 1963 & $1,530.6$ & 6.1 & 6.7 & 7.3 & 8.2 \\
\hline 1964 & $1,531.1$ & 5.7 & 6.0 & 6.6 & 7.4 \\
\hline 1965 & $1,591.1$ & 5.4 & 5.8 & 6.3 & 7.2 \\
\hline 1966 & $1,661.1$ & 5.4 & 5.8 & 6.3 & 7.2 \\
\hline 1967 & $1,739.0$ & 5.4 & 5.8 & 6.4 & 7.2 \\
\hline 1968 & $1,923.2$ & 5.6 & 6.0 & 6.6 & 7.4 \\
\hline 1969 & $1,948.2$ & 5.3 & 5.6 & 6.1 & 6.9 \\
\hline 1970 & $1,967.8$ & 4.9 & 5.2 & 5.7 & 6.4 \\
\hline 1971 & $2,275.0$ & 5.1 & 5.3 & 6.1 & 6.9 \\
\hline 1972 & $2,743.5$ & 5.4 & 5.8 & 6.6 & 7.4 \\
\hline 1973 & $3,126.9$ & 5.2 & 5.5 & 6.3 & 7.1 \\
\hline 1974 & $2,996.5$ & 4.5 & 4.8 & 5.5 & 6.2 \\
\hline
\end{tabular}


Table 2 (continued)

\begin{tabular}{|c|c|c|c|c|c|}
\hline & $\begin{array}{l}\text { Unadjusted } \\
\text { estates } £ \text { million }\end{array}$ & $\begin{array}{l}\text { as } \% \text { national } \\
\text { income }\end{array}$ & $\begin{array}{l}\text { Corrected } \\
\text { for non-filers } \\
\text { as } \% \text { national } \\
\text { income }\end{array}$ & $\begin{array}{l}\text { Plus correction for } \\
\text { exempt assets and } \\
\text { undervaluation as } \\
\% \text { national income }\end{array}$ & $\begin{array}{l}\text { Plus gifts inter vivos } \\
\text { as } \% \text { national income }\end{array}$ \\
\hline 1975 & $3,441.8$ & 4.1 & 4.4 & 5.1 & 5.7 \\
\hline 1976 & $3,910.4$ & 4.0 & 4.3 & 5.0 & 5.6 \\
\hline 1977 & $3,866.6$ & 3.4 & 3.8 & 4.3 & 4.8 \\
\hline 1978 & $4,823.6$ & 3.7 & 4.0 & 4.6 & 5.2 \\
\hline 1979 & $5,921.3$ & 4.0 & 4.3 & 4.9 & 5.5 \\
\hline 1980 & $6,883.6$ & 4.0 & 4.2 & 4.9 & 5.3 \\
\hline 1981 & $7,628.0$ & 4.0 & 4.3 & 5.0 & 5.4 \\
\hline 1982 & $8,210.8$ & 4.0 & 4.1 & 4.8 & 5.2 \\
\hline 1983 & $9,195.3$ & 4.0 & 4.2 & 4.8 & 5.2 \\
\hline 1984 & $10,371.6$ & 4.2 & 4.7 & 5.3 & 5.8 \\
\hline 1985 & $11,481.7$ & 4.3 & 4.8 & 5.4 & 5.9 \\
\hline 1986 & $12,783.4$ & 4.4 & 5.0 & 5.7 & 6.2 \\
\hline 1987 & $14,306.4$ & 4.5 & 5.0 & 5.8 & 6.2 \\
\hline 1988 & $17,320.1$ & 4.9 & 5.4 & 6.1 & 6.6 \\
\hline 1989 & $20,121.9$ & 5.2 & 5.5 & 6.4 & 6.9 \\
\hline 1990 & $18,580.7$ & 4.4 & 4.8 & 5.6 & 6.0 \\
\hline 1991 & $19,453.2$ & 4.5 & 4.9 & 5.6 & 6.1 \\
\hline 1992 & $19,511.2$ & 4.3 & 4.7 & 5.4 & 5.8 \\
\hline 1993 & $22,196.3$ & 4.6 & 5.0 & 5.7 & 6.2 \\
\hline 1994 & $21,758.5$ & 4.2 & 4.5 & 5.2 & 5.6 \\
\hline \multicolumn{6}{|l|}{1995} \\
\hline 1996 & $25,215.3$ & 4.4 & 4.7 & 5.9 & 6.3 \\
\hline 1997 & $25,716.3$ & 4.2 & 4.5 & 5.6 & 6.0 \\
\hline 1998 & $29,619.7$ & 4.5 & 4.8 & 5.9 & 6.4 \\
\hline 1999 & $34,603.6$ & 5.1 & 5.4 & 6.7 & 7.3 \\
\hline \multicolumn{6}{|l|}{2000} \\
\hline 2001 & $41,911.3$ & 5.5 & 5.8 & 7.2 & 7.8 \\
\hline 2002 & $44,685.0$ & 5.5 & 5.8 & 7.2 & 7.8 \\
\hline 2003 & $49,998.0$ & 5.9 & 6.1 & 7.6 & 8.2 \\
\hline \multicolumn{6}{|l|}{2004} \\
\hline 2005 & $56,052.0$ & 5.8 & 6.0 & 7.5 & 8.1 \\
\hline 2006 & $59,444.0$ & 5.8 & 6.1 & 7.6 & 8.2 \\
\hline 2007 & $62,062.0$ & 5.7 & 6.0 & 7.4 & 8.0 \\
\hline 2008 & $61,416.0$ & 5.4 & 5.4 & 6.8 & 7.4 \\
\hline
\end{tabular}

sector, where privatisation changed the reality and not just the form of ownership. The government policy created individual property rights to what had previously been communal wealth, and the transmission of private wealth increased on this account.

So far I have focused on the past three decades. From Fig. 7 we can see that there was not just a simple U-shape. There was indeed a large fall from the 1930s to the 1970s: the adjusted wealth-national income ratio was 17 in 1932 but 4.8 in 1977. But before that, there 
had been periods of fall (5 percentage points from 1899 to 1914) and rise (6 percentage points from 1921 to 1932). One could say that in the UK we have to explain, not one U, but two U-shapes.

The basic accounting equation used by Piketty (2011) is that the ratio of transmitted wealth, $B_{t}$, to national income, $Y_{t}$, is equal in year $t$ to

$$
B_{t} / Y_{t}=b_{y t}=m_{t} \mu_{t}^{*} W_{t} / Y_{t}
$$

where $m_{t}$ is the mortality rate, $\mu_{t}^{*}$ is the ratio of the average wealth of decedents (corrected for gifts inter vivos) relative to the average wealth of the living, and $W_{t}$ denotes total personal wealth. Another way of expressing the relationship is that the ratio of transmitted wealth to total personal wealth is equal to $b_{w t}=m_{t} \mu_{t}^{*}$. In the case of France, he observed that "the historical decline in the mortality $m_{t}$ seems to have been (partially) compensated by an increase in the $\mu_{t}^{*}$ ratio. Consequently, the product of the two, that is the inheritancewealth ratio $b_{w t}=m_{t} \mu_{t}^{*}$, declined much less than the mortality rate. . This is the central fact that needs to be explained" (Piketty 2011, page 1105).

Figure 9 shows the ratio $b_{y t}$ for the UK. It may be seen that in the UK the mortality rate (for persons aged 20 and over) was broadly constant from 1896 to the 1970s, whereas the implied value of $\mu^{*}$ rose in the 1920s and then fell until the end of the 1970s, when it levelled off and began to rise in the 1990s. The situation described by Piketty, with mortality declining and $\mu^{*}$ rising, applied therefore to the most recent part of the upturn in inheritance. From 1977 to 2006, the rise in the $B_{t} / Y_{t}$ ratio by a factor of 1.69 can be seen as the product of 0.75 (mortality decline) 1.23 (rise in $\mu^{*}$ ) and 1.83 (rise in $W_{t} / Y_{t}$ ). In contrast, the earlier upturn, from 1921 to 1932 by a factor of 1.54 can be seen as the product of 1.06 (slight mortality increase), 1.03 (virtually constant $\mu^{*}$ ) and 1.41 (rise in $W_{t} / Y_{t}$ ).

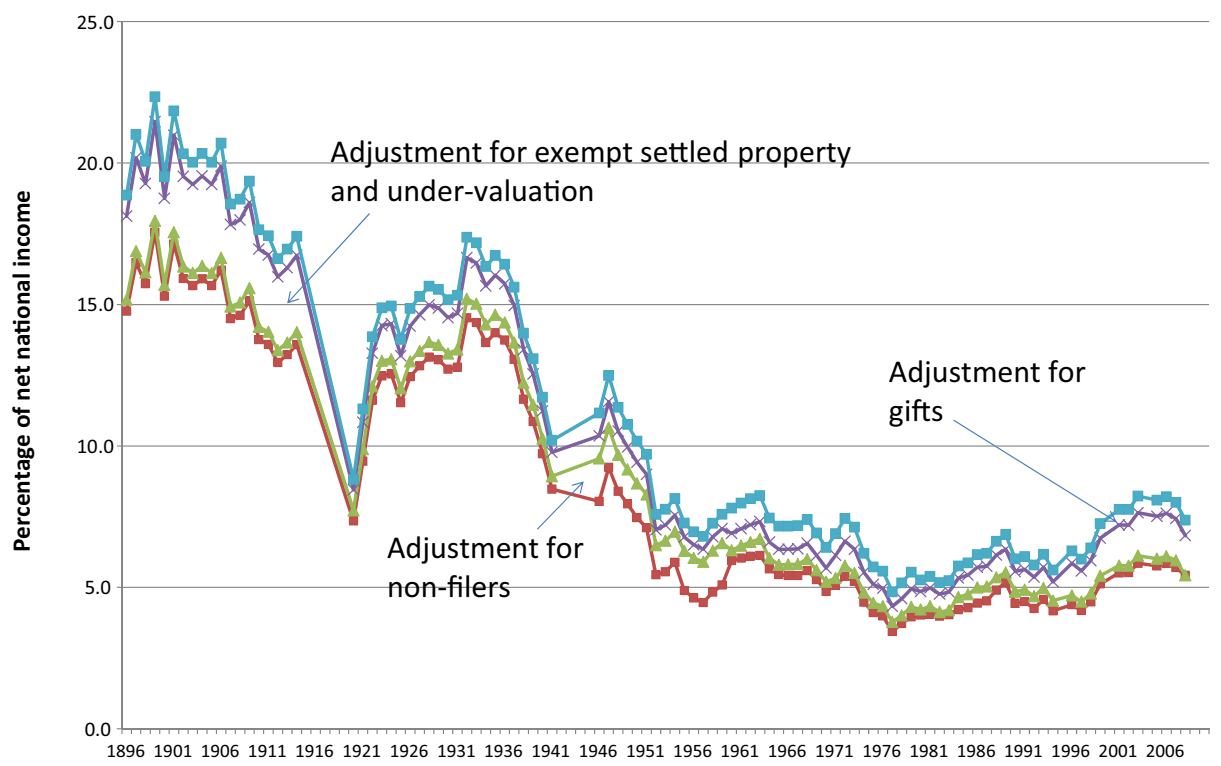

Fig. 7 Transmitted wealth in the United Kingdom between 1896 and 2008, as percentage of net national income 


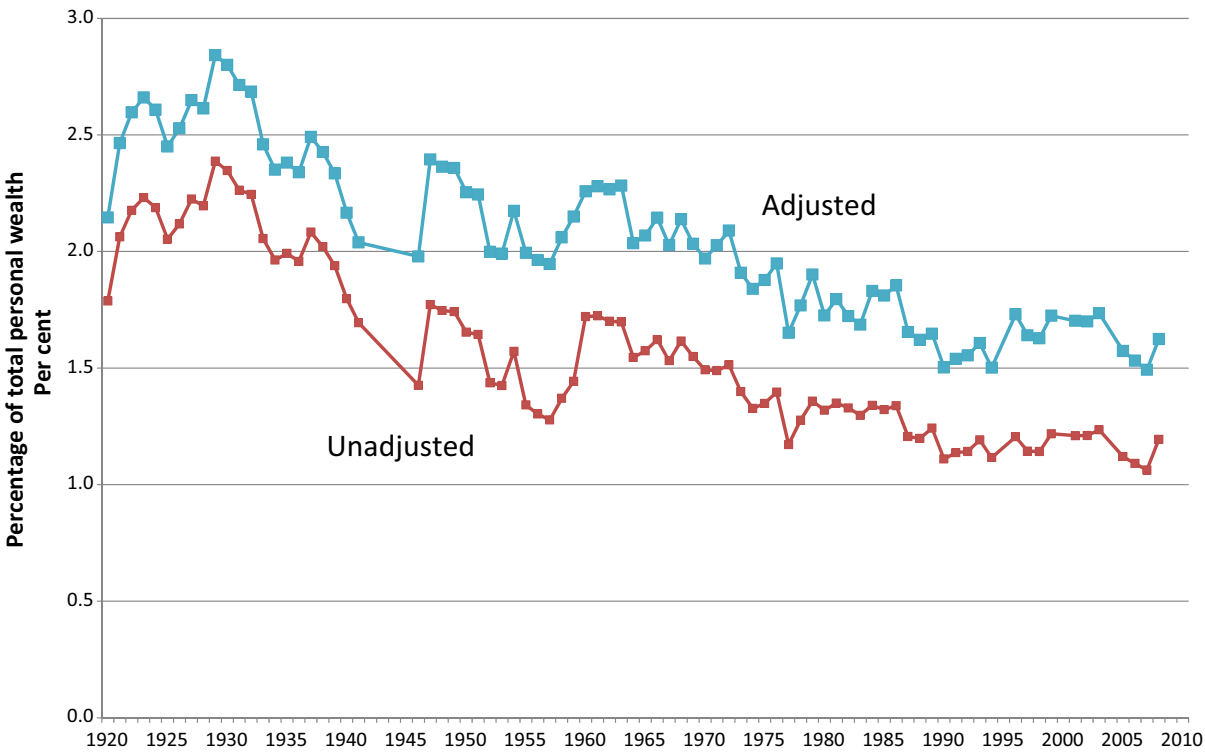

Fig. 8 Transmitted wealth in the United Kingdom from 1920 to 2008, as percentage of total personal wealth

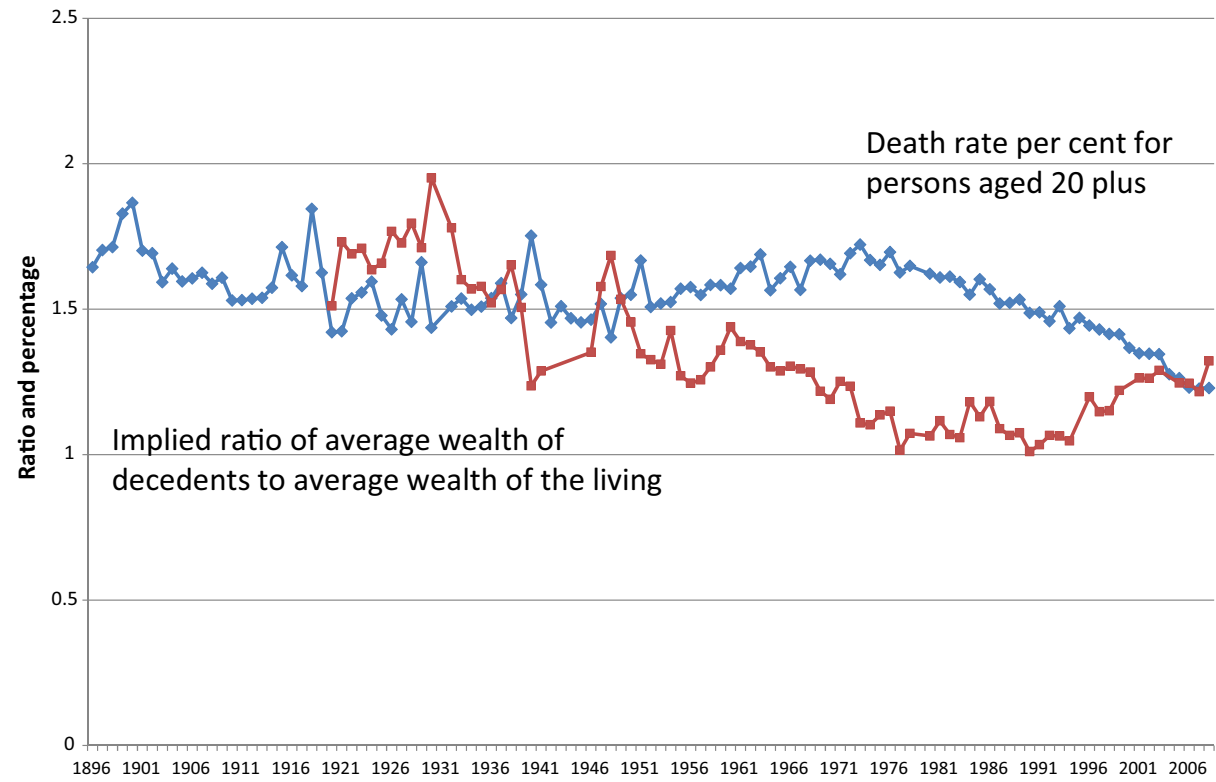

Fig. 9 Accounting for changes in the ratio of transmitted wealth to net national income in the United Kingdom from 1896 to 2008 


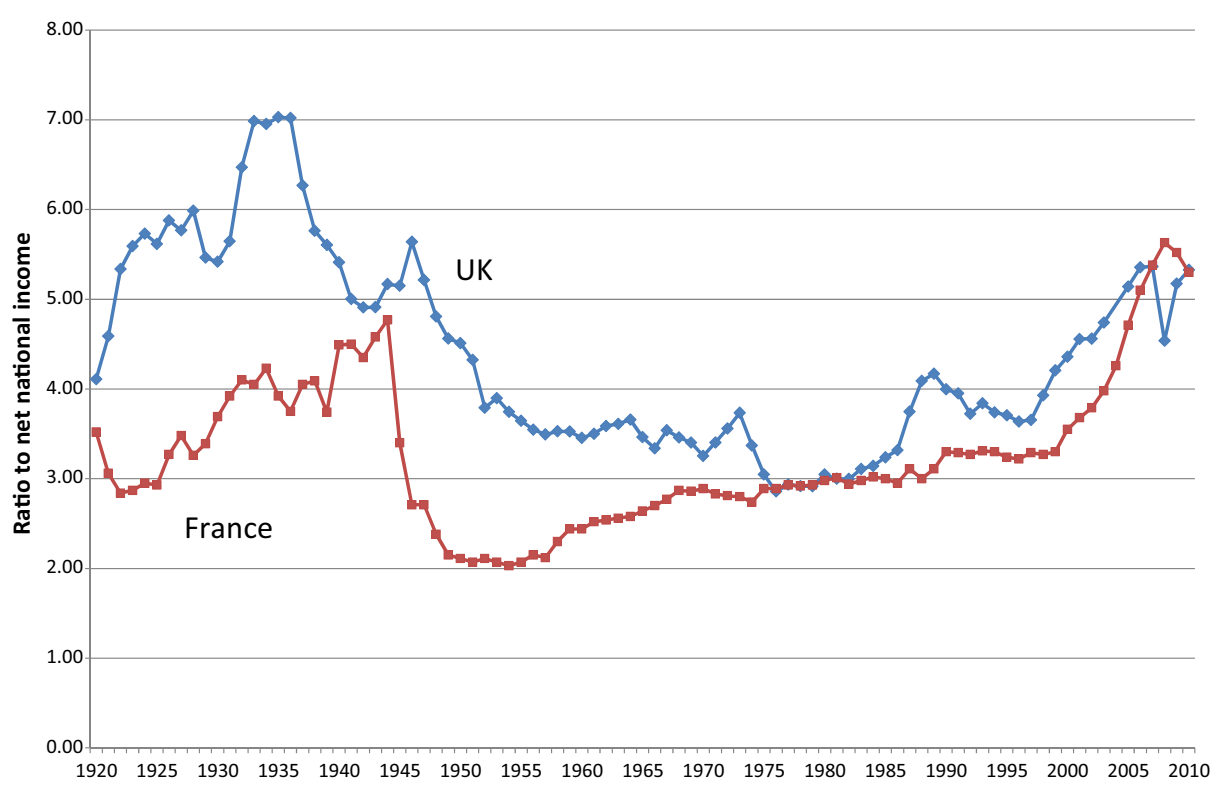

Fig. 10 Ratio of personal wealth to national income France and the UK

\section{Comparison with France}

This paper originated as a response to the challenge of Piketty (2011) who looked at the overall wealth-income ratio for the UK (and the US), but not at the estate data. The conclusion he drew about the UK, on the basis of admittedly piecemeal data, was that the private wealth-national income ratio was 6.5 to 7.5 at the end of the nineteenth century, down to 3.5 to 4 in the $1950 \mathrm{~s}-1970 \mathrm{~s}$, and up at 4.5 to 5.5 at the end of the twentieth century. Here I have linked different series for the UK back to 1920. As may be seen from Fig. 10, the French and UK series are remarkably close in the latter decades, showing a rise from 3 to 5 from the end of the 1970s to the present. The figures were also close at the outbreak of the Second World War, but in the intervening period were rather different. In France the rise in the ratio started in the 1950s; in the UK, the fall was less steep in wartime but continued until the mid-1970s. The inter-war period was also different. The ratios were close in 1920, but then followed a different trajectory.

How do these similarities and differences play out in terms of inheritance? Figure 11 reproduces the estimates of Piketty for France (covering here only over the shorter-113 year-period for which we have UK estimates). It shows in particular the major contribution of gifts inter vivos to the recent up-turn. The raw estate data display a rise in the bequestnational income ratio from 1.4 per cent in 1950 to 3.7 per cent in 2006, whereas the adjusted figure rises from 2.5 to 11 per cent. The rise from 1977 to 2006 is by a factor of 1.61 (unadjusted) and 2.39 (adjusted). The upward adjustment for gifts inter vivos in France is over 80 per cent in the 2000 s.

The contribution of gifts is one reason that the upturn is more marked in France than in the UK - see Fig. 12, where transmitted wealth, adjusted for both countries, is shown as a percentage of national income. In terms of the earlier decomposition, the rise in the $B_{t} / Y_{t}$ 


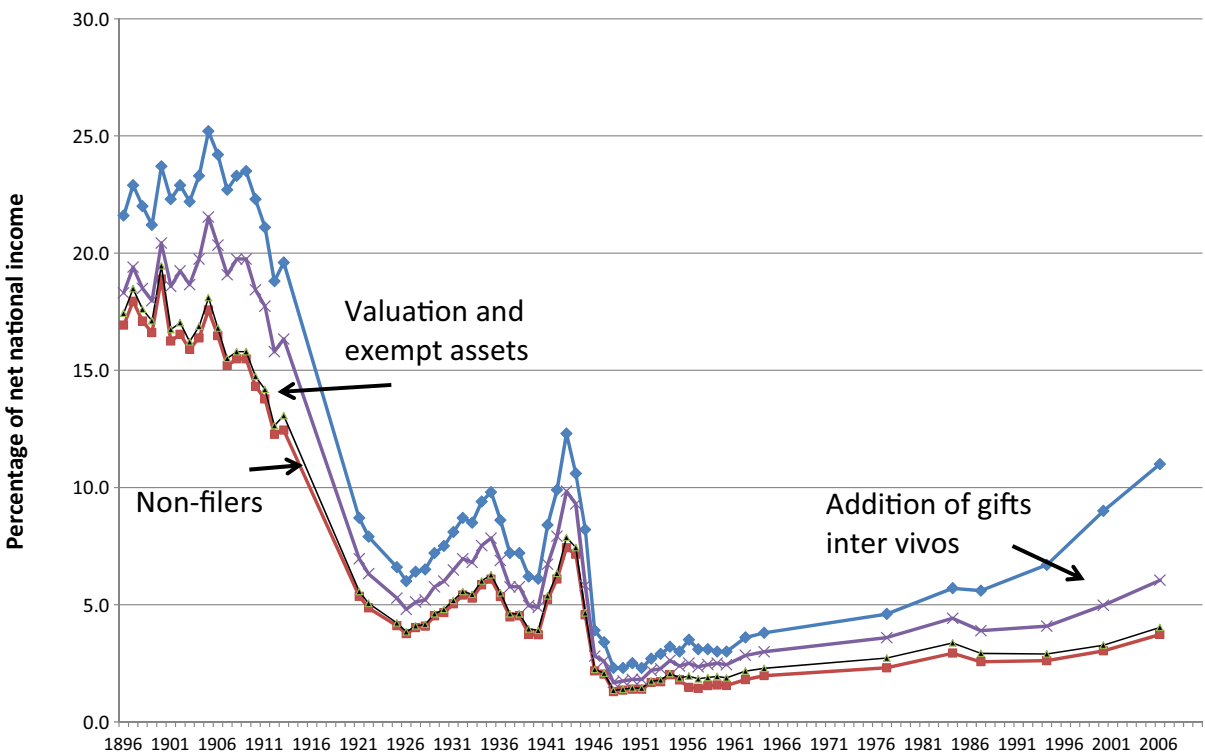

Fig. 11 Transmitted wealth in France as percentage of net national income from 1896 to 2005

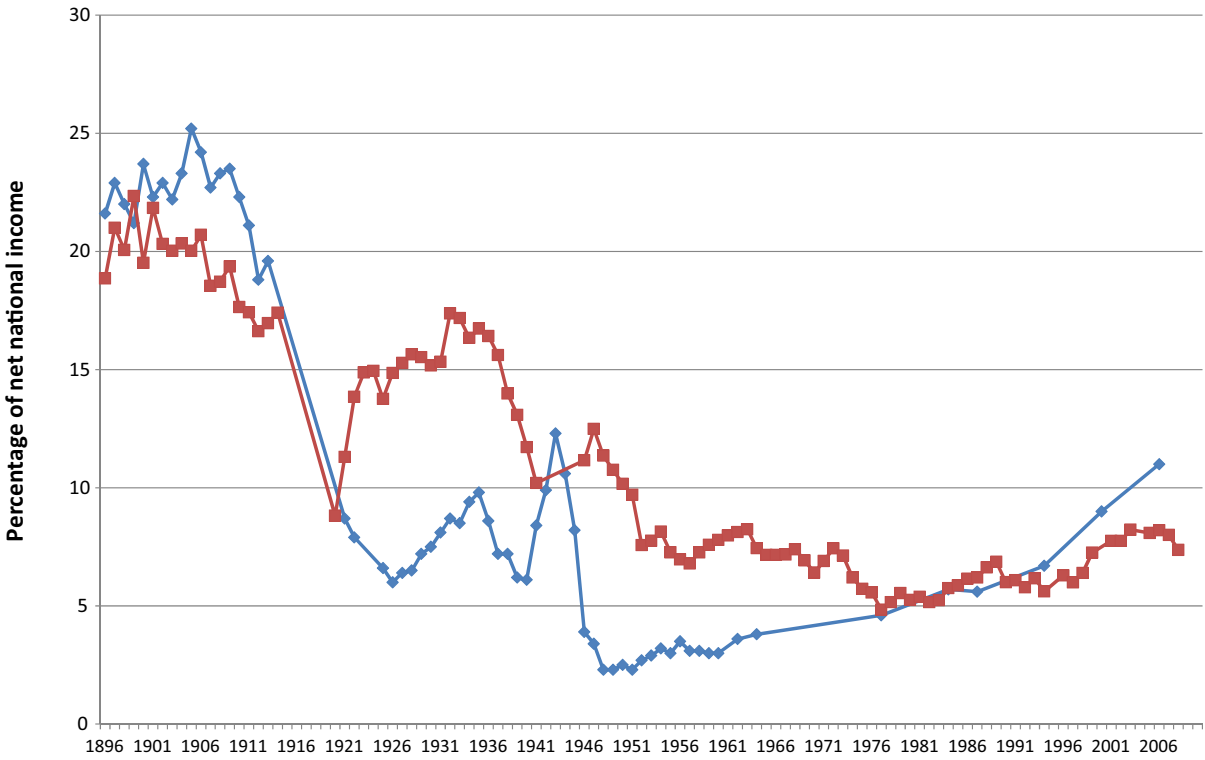

Fig. 12 Comparison of France and the United Kingdom: transmitted wealth as percentage of net national income from 1896 to 2008 


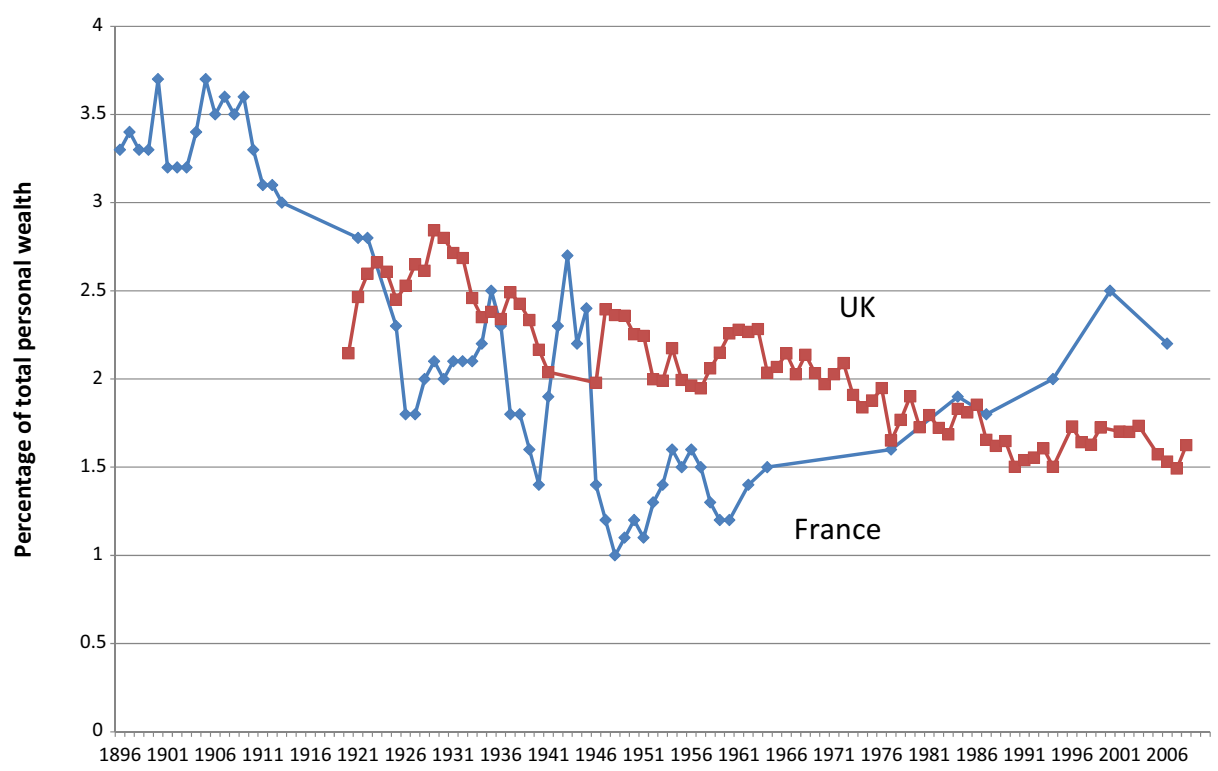

Fig. 13 Comparison of France and the United Kingdom: transmitted wealth as percentage of personal wealth from 1896 to 2008

ratio in France by a factor of 2.39 between 1977 and 2006 can be seen as the product of 0.79 (mortality decline), 1.75 (rise in $\mu^{*}$ ), and 1.74 (rise in $W_{t} / Y_{t}$ ). The first is very similar to the UK (0.75), and the third is quite close (1.83 in the UK). The difference is in $\mu^{*}(1.23$ in the UK). It is quite possible that the UK estimates have under-stated gifts. Such an understatement would also account for the differing directions of change in transmitted wealth expressed as a percentage of total personal wealth-see Fig. 13.

The other striking difference is that there was a strong recovery in the UK after the First World War, and less of a fall after the Second World War, which took the transmitted wealth to a level that was higher than in France for a sustained period (leaving aside the war years for which there are no UK data) from 1920 to the late 1970s. As a result, the weight of accumulated transmitted wealth must have been higher in the UK.

Finally, it should be noted that in the UK, with its freedom of bequest, it is possible that the estate figures include more sideways transfers than is the case in France, and to this degree over-state the extent of inter-generational transmission.

\section{Conclusions}

Changes in the extent of aggregate inheritance can have major economic and social consequences. A society where each year people can expect to receive in inheritance a sum of around a fifth of total income is very different from one where the sum is around a fiftieth. The repercussions are likely to be seen in the labour market, in investment opportunities, and in the housing market. In the UK, the level of transmitted wealth has not reached the 12 per cent of income in France (in 2006); nor did it fall so low. Expressed as a percentage 


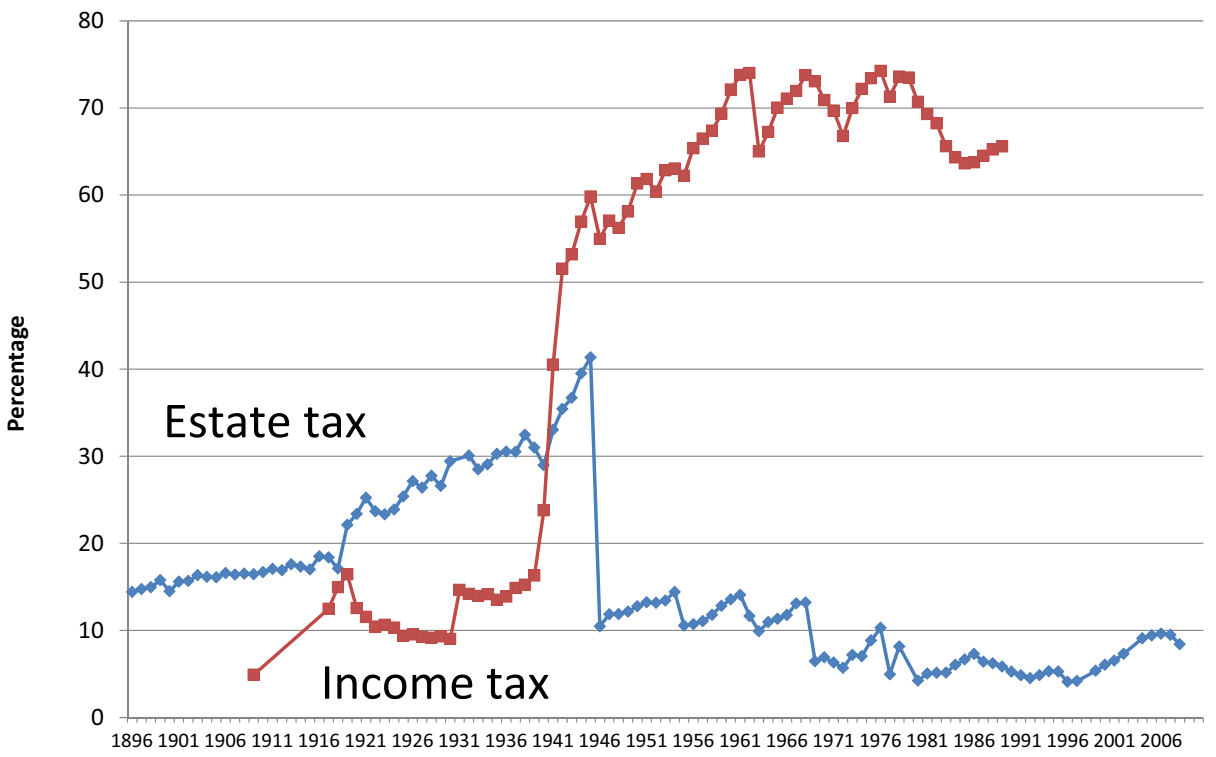

Fig. 14 Adults liable to the income tax (as percentage of total adults), and decedents liable to the estate tax (as percentage of total adult decedents) in the United Kingdom from 1896 to 2010

of national income, transmitted wealth fell to under 5 per cent in the 1970 s and has risen to around 8 per cent. The figure would be lower if all inter-spousal transfers were subtracted, but would be higher if gifts inter vivos are under-stated.

The significance of an 8 per cent figure should not be minimised. In 2008/9 it was the same percentage as that of private pensions and annuities in total gross household income. In this context, we should note that the taxation of wealth transfers was in the past a significant source of government revenue. If inheritance is returning, then we need to look again at its role as a basis for taxation. As is shown in Fig. 14, until the Second World War a UK citizen was, statistically, more likely to pay Estate Duty at death than to pay income tax whilst living. This is far from the case today, and this underlies calls for a reformed capital receipts tax, as proposed by the Mirrlees Review (2011), and by Atkinson (1972).

Open Access This article is distributed under the terms of the Creative Commons Attribution 4.0 International License (http://creativecommons.org/licenses/by/4.0/), which permits unrestricted use, distribution, and reproduction in any medium, provided you give appropriate credit to the original author(s) and the source, provide a link to the Creative Commons license, and indicate if changes were made.

\section{Appendix: Data sources}

\section{Total national and personal income}

The national income series is from Mitchell (1988, pages 828-830) up to 1980, then the National Income Blue Books 1997, 2004 and 2010, Table 1.1.

\section{Total personal wealth}


The personal wealth series is compiled by linking several different series, with definitions that are not necessarily identical. It works back from the HMRC series for total marketable wealth, 1990-2005 from the HMRC website, Table 13.4, 1984 to 1989 from IRS 2000, Table 13.4, 1981 to 1983 from IRS 1998, Table 13.4, 1979 to 1980 from IRS 1996, Table 13.4, 1976 to 1978 from IRS 1992, Table 11.4, linked at 1976 to series 1948 to 1976 from Blake and Orszag (1999), Table 12 (not including pension wealth), linked at 1948 to series 1920-1948 from Solomou and Weale (1997), Table 6 (net personal wealth including durables). The series has been extrapolated beyond 2005 in line with household net worth as given in the National Income Blue Book 2011, Table 10.10.

\section{Mortality rates}

The series for total deaths at age 20 and over is from the Annual Abstract of Statistics (AAS) and its predecessor, the Statistical Abstract for the United Kingdom (StA): 1911 to 1925 from StA 1911-1925, Table 21, where the deaths for the age group 15-19 has been taken as half that for 15-24; 1926 to 1930 from StA 1913 and 1917-1930, Table 24, where the deaths for the age group 15-19 has been taken as half that for 15-24; 1932 to 1941 from AAS 1935-1946, Tables 20 and 21; 1942 to 1965 from AAS 1966, Tables 28-31; 1966 to 1978 from AAS 1981, Table 2.29; 1980 and 1981 from AAS 2002, Table 5.18, 1982-2002 from AAS 2004, Table 5.19. These figures relate to the calendar year.

\section{Wealth of the excluded population 1896-1923}

The method is similar to that used by Clay (1925) to make estimates for 1912 and 1921. His total is made up of household goods plus "working-class savings". For household goods, we have taken the 1921 figure of Clay and assumed a constant real value in other years, applying the ONS composite consumer price index. For each of the savings categories, we have obtained comparable series for the totals of each type, using the sources listed below. It should be noted that we have not included the funds of Friendly Societies, Trade Unions, of the National Health Insurance Fund, nor the Unemployment Insurance Fund, on the grounds that these do not form part of inheritance. This reduces Clay's UK total for 1912 from $£ 546$ million to $£ 452$ million. Clay adjusts his total by a factor to allow for the part of these types of saving that are held by those covered by the estate duty statistics. He adjusts by subtracting 14 per cent in 1912 and 21 per cent in 1921. Here we have instead followed the estimates made by Radice (1939) of the proportions attributable to the excluded population; see Atkinson and Harrison (1978, pages $302-3)$.

The sources for specific categories are as follows:

a. Savings Banks deposits: Post Office

From Mitchell (1988), pages 671-2.

b. Savings Banks deposits: Trustee Ordinary Departments (railway not included)

From Mitchell (1988), pages 671-2.

c. Savings Banks deposits: Trustee Special Investment Departments

From Mitchell (1988), pages 671-2.

d. Government stock held by Post Office and Trustee Savings Banks 
From StA 1890-1904 (Cd 2622), Tables 88 and 89, StA 1899-1913 (Cd 7636), Tables 93 and 94, StA 1910-1924, Tables 88 and 89.

\section{e. Building societies}

From StA 1890-1904, Table 92, StA 1899-1913, Table 98, StA 1906-1920, Table 87, StA 1908-1922, Table 84 (Great Britain figures extrapolated), StA StA 1910-1924, Table 92, figure for 1923 based on proportionate growth in share capital (change in form of table), which agrees with increase in deposits shown in Radice (1939, Table VII).

\section{f. Industrial co-operative societies}

From StA 1890-1904, Table 93, StA 1899-1913, Table 99, StA 1908-22, Table 85, StA 1910-24, Table 93 (increase of 1923 over 1922 used to link to earlier series), where sum of share capital and amounts due to depositors is used to link to 1912 and 1921 figures given by Clay (a linear fit to these two numbers).

g. Registered Friendly societies (not included)

From Report of the Chief Registrar of Friendly Societies for the year ending 31 December 1899, page 36, for the year ending 31 December 1901, page 29, year ending 31 December 1901, page 25, year ending 31 December 1903, page 28, year ending 31 December 1904, page 31. Year ending 31 December 1907, page 48, year ending 31 December 1908, page 44, year ending 31 December 1909, page 42, year ending 31 December 1910, page 37, year ending 31 December 1911, page 41, year ending 31 December 1912, page 60, year ending 31 December 13, page 80, year ending 31 December 1917, page 93, figures for 1896-7, 1900, 1904-5, 1917-20, and 1922-3 interpolated linearly.

h. Industrial life assurance, life funds

Taken from StA 1890-1904, Table 94, StA 1899-1913, Table 100, then 1914 to 1923 from Report of the Industrial Assurance Commissioner for the year ended 31st December 1925, page 124 (industrial assurance companies, to match figure of Clay), figure for 1913 interpolated.

The resulting total for 1921 is $£ 650$ million, which, on the basis of Clay's estimate of 13.5 million persons, amounts to some $£ 48$ per head. The estate duty threshold was then $£ 100$. The Atkinson and Harrison (1978) central estimate for 1923 was $£ 825$ million, adjusted to a Great Britain basis. As noted in the text, this included jointly held property that is not covered in the estimate here.

\section{References}

Alvaredo, F., Atkinson, A.B., Morelli, S.: Top wealth shares in the UK over more than a century. J. Public Econ., Forthcoming (2018)

Alvaredo, F., Atkinson, A.B., Morelli, S.: Top wealth shares in the UK over more than a century. CEPR DP 11759 (2017)

Atkinson, A.B.: Unequal Shares. Allen Lane and Penguin Books, London (1972)

Atkinson, A.B.: The distribution of top incomes in the United Kingdom 1908-2000. In: Atkinson, A.B., Piketty, T. (eds.) Top Incomes over the Twentieth Century. Oxford University Press, Oxford (2007)

Atkinson, A.B., Backus, P., Micklewright, J.: Charitable bequests and wealth at death in Great Britain. Econ. J. 127(65), F1-F23 (2017) 
Atkinson, A.B., Gordon, J.P.F., Harrison, A.J.: Trends in the shares of top wealth-holders in Britain, 19231981. Oxf. Bull. Econ. Stat. 51, 315-332 (1989). (data are contained in discussion paper version, McMaster University, Department of Economics Working Paper 86-13)

Atkinson, A.B., Harrison, A.J.: The Distribution of Personal Wealth in Britain. Cambridge University Press, Cambridge (1978)

Blake, D., Orszag, J.M.: Annual estimates of personal wealth holdings in the United Kingdom since 1948. Appl. Financ. Econ. 9, 397-421 (1999)

Campion, H.: Public and Private Property in Great Britain. Oxford University Press, London (1939)

Clay, H.: The distribution of capital in England and Wales. Transactions of the Manchester Statistical Society, pp. 53-80 (1925)

Central Statistical Office: Personal sector balance sheets and current developments in Inland Revenue estimates of personal wealth. HMSO, London (1978)

Dunn, A.T., Hoffman, P.D.R.B.: Distribution of wealth in the United Kingdom: effect of including pension rights, and analysis by age groups. Rev Income Wealth 29, 243-282 (1983)

Hills, J., Glennerster, H.: Public policy, wealth, and assets: a complex and inconsistent story. In: Hills, J., Bastagli, F., Cowell, F., Glennerster, H., Karagiannaki, E., McKnight, A. (eds.) Wealth in the UK: Distribution, Accumulation and Policy. Oxford University Press, Oxford (2013)

Holmans, A.: Housing. In: Halsey, A.H., Webb, J. (eds.) Twentieth Century British Social Trends. Macmillan, London (2000)

Horsman, E.G.: The avoidance of Estate Duty by gifts inter vivos. Econ. J. 85, 516-530 (1975)

Karagiannaki, E.: Recent trends in the size and the distribution of inherited wealth in the UK, CASEpaper 146, London School of Economics (2011)

Karagiannaki, E.: The impact of inheritance on the distribution of wealth: Evidence from the UK, CASEpaper 148, London School of Economics (2011a)

Karagiannaki, E.: The magnitude and correlates of inter-vivos transfers in the UK, CASEpaper 151, London School of Economics (2011b)

Lydall, H.F., Tipping, D.G.: The distribution of personal wealth in Britain. Bull. Oxf. Univ. Inst. Econ. Stat. 23(1), 83-104 (1961)

Mirrlees, J.A.: Tax by Design. Oxford University Press, Oxford (2011)

Mitchell, B.R.: British Historical Statistics. Cambridge University Press, Cambridge (1988)

Modigliani, F.: Life cycle, Individual thrift, and the wealth of nations. Am. Econ. Rev. Am. Econ. Assoc. 76(3), 297-313 (1986)

Piketty, T.: On the long-run evolution of inheritance: France 1820-2050 Data Appendix, Paris School of Economics (2009)

Piketty, T.: On the long-run evolution of inheritance: France 1820-2050. Q. J. Econ. 126, 1071-1131 (2011)

Prest, A.R.: Review of Atkinson (1972). Economica 40, 219-221 (1973)

Radice, E.A.: Savings in Great Britain 1922-1935. Oxford University Press, London (1939)

Revell, J.R.S.: The Wealth of the Nation. Cambridge University Press, Cambridge (1967)

Robson, M.H., Timmins, R.K.: Discretionary Trusts-A Research Study. Inland Revenue, London (1988)

Royal Commission on the Distribution of Income and Wealth: Third Report on the Standing Reference, Cmnd. 6999. HMSO, London (1977)

Sandford, C.T.: Taxing Personal Wealth. Allen and Unwin, London (1971)

Solomou, S., Weale, M.: Personal sector wealth in the United Kingdom, 1920-56. Rev. Income Wealth 43, 297-318 (1997)

Tait, A.A.: The Taxation of Personal Wealth. University of Illinois Press, Urbana (1967)

Wedgwood, J.: The Economics of Inheritance. Penguin Books, Harmondsworth $(1929,1939)$

Whalley, J.: Estate Duty as a 'voluntary' tax: evidence from Stamp Duty statistics. Econ. J. 84, 638-644 (1974)

Wolff, E., Gittleman, M.: Inheritance and the distribution of wealth. Or whatever happened to the great inheritance boom? BLS Working Paper 445, U.S. Department of Labor (2011)

Wright, S.: Measures of stock market value and returns for the U.S. nonfinancial corporate sector, 1900-2002. Rev. Income Wealth 50, 561-584 (2004) 